A. J. Senchack, Jr. University of Texas at Austin John D. Martin University of Texas at Austin

\title{
Program Trading and Systematic Risk
}

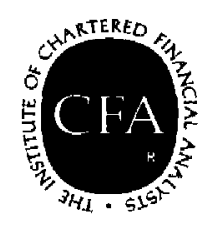

The Research Foundation of

The Institute of Chartered Financial Analysts 


\section{Program Trading and Systematic Risk}


(C) 1990 The Research Foundation of the Institute of Chartered Financial Analysts

All rights reserved. No part of this publication may be reproduced, stored in a retrieval system, or transmitted, in any form or by any means, electronic, mechanical, photocopying, recording, or otherwise, without the prior written permission of the copyright holder.

This publication is designed to provide accurate and authoritative information in regard to the subject matter covered. It is sold with the understanding that the publisher is not engaged in rendering legal, accounting, or other professional service. If legal advice other expert assistance is required, the services of a competent professional should be sought.

From a Declaration of Principles jointly adopted by a Committee of the American Bar Association and a Committee of Publishers.

ISBN 10-digit: 0-943205-09-3 ISBN 13-digit: 978-0-943205-09-0

Printed in the United States of America

Joni L. Tomal, Editor

Nina D. Hutchinson, Typography/Layout

November 1990 


\section{Mission}

The mission of the Research Foundation is to identify, fund, and publish research material that:

- expands the body of relevant and useful knowledge available to practitioners;

- assists practitioners in understanding and applying this knowledge; and

- enhances the investment management community's effectiveness in serving clients.

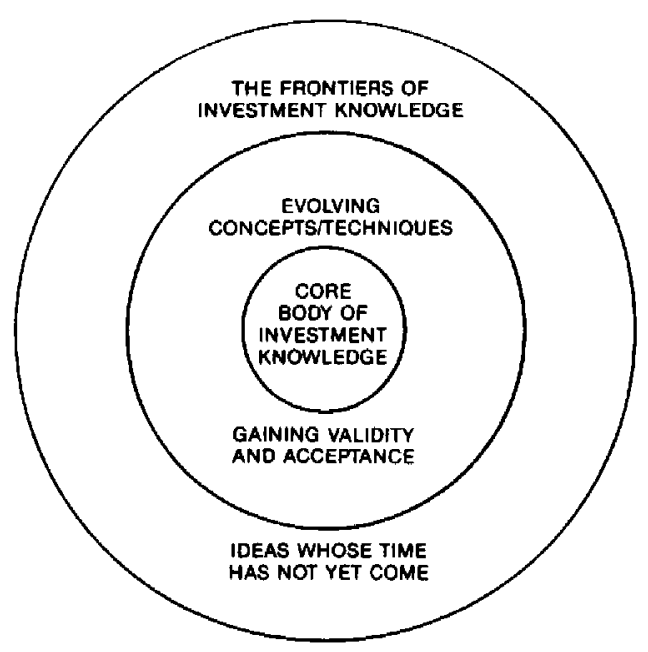

The Research Foundation of

The Institute of Chartered Financial Analysts

P.O. Box 3668

Charlottesville, Virginia 22903

(804) $977-6600$ 


\section{TABLE OF CONTENTS}

Acknowledgements $\ldots \ldots \ldots \ldots \ldots \ldots \ldots$ ix

Foreword $\ldots \ldots \ldots \ldots \ldots \ldots \ldots \ldots \ldots \ldots$

Introduction $\ldots \ldots \ldots \ldots \ldots \ldots \ldots \ldots$

Chapter 1. Analytical Framework of the Study . . . . . . . 5

Chapter 2. Changes in Percentage Systematic Risk . . . . . 13

Chapter 3. Changes in the Covariability of Individual Stocks . . 21

Chapter 4. Implications for Investment Analysis . . . . . . 37

Chapter 5. Conclusions . . . . . . . . . . . . . . 41

Appendix $\ldots \ldots \ldots \ldots \ldots \ldots \ldots \ldots \ldots$

References $\ldots \ldots \ldots \ldots \ldots \ldots \ldots \ldots$ 


\title{
ACKNOWLEDGEMENTS
}

We benefitted from discussions with the finance faculty at the University of Texas at Austin. A special thanks goes to Chuck D'Ambrosio, Research Director, and members of the Review Board of the Research Foundation for their helpful comments. The research assistance of Juan Alberto Siu and the editorial work of Katrina Sherrerd and her staff also are gratefully acknowledged. In addition to the financial support of the Research Foundation of the ICFA, we also appreciate the financial support of the University Research Institute at the University of Texas at Austin.

\author{
A.J. Senchack, Jr. \\ John D. Martin \\ University of Texas at Austin
}




\section{FOREWORD}

Immediately after the introduction of stock index futures and index options in 1982, practitioners implemented strategies for using them. Although many of these strategies, especially program trading, are controversial, derivative instruments are here to stay, and the more we can learn about them the better.

Senchack and Martin help us considerably in this effort. In their study they hypothesize that systematic risk as a percentage of total risk increases after stock index futures and index options begin trading. Specifically, they investigate the following interrelated questions: (1) Does the systematic risk of the Major Market Index (MMI), the S\&P 500 Composite Index (S\&P 500), and of stocks in general, as a percentage of total risk, increase during the 1980-87 period? (2) If it does, what happens to the covariability among and between the indexes and the individual stocks' returns? The authors' findings have many implications for practitioners.

\section{What the Authors Find}

This is how they approached the problem. By definition, total risk is composed of systematic and unsystematic components. For convenience, systematic risk as a percentage of total risk will often be called percentage systematic risk. Senchack and Martin study the percentage of total risk that is systematic before and after the introduction of index futures and options trading. Two indexes, the MMI and the S\&P 500, and five sample portfolios are used for the analysis. The sample portfolios are constructed as follows: all 20 stocks in the MMI; two 20-stock random samples from the S\&P 500; and two 20-stock random samples in neither the MMI nor S\&P 500 yet comparable in size to the S\&P 500. These seven asset bundles are compared within and among each other as well as with two benchmark portfolios, the equally weighted and value-weighted indexes developed by the Center for Research in Security Prices (CRSP).

In addition to the entire $1980-87$ period, three subperiods are studied: one before and one after index futures and index options were introduced, and a transition period. The data are also analyzed year-over-year.

The market model is used to estimate the systematic and nonsystematic risk components. Depending on the context, systematic risk is measured by beta or $\mathrm{R}^{2}$. The former is an estimate of an asset's volatility. In this study the 
latter explains the percentagevariation in returns accounted for by the variation in returns of a benchmark portfolio.

With that as the analytical model, several conclusions surface. The main one is that after the introduction of index futures and options, large-capitalization stocks experience a statistically significant increase in systematic risk as a percentage of total risk, but small-capitalization stocks do not. Moreover, the S\&P 500's percentage systematic risk increases more than that of the MMI, and $S \& P 500$ returns are more highly correlated with both market proxies than those of the MMI.

The authors also find that, on average, there is a significant increase in covariability among larger index and non-index stocks' returns in the postfutures period compared to their historical (pre-futures) relationship. The increase in correlations was not evident in smaller index or non-index stocks.

An even more dramatic increase in correlations is found when the 1987 period is studied in terms of high- and low-intensity program trading days. With the exception of small non-index stocks, the average correlation of all stocks within each of their samples tends to be less on low-intensity days than on high-intensity ones. These results are consistent with the idea that index futures and options increase the comovement among index stocks. Moreover, a positive relation exists between firm size and the relative difference between correlations on high- and low-intensity days. Yet, size alone may account for the high covariability among the large non-index stocks, because their size makes them candidates for core portfolios that are subject to program trading.

A significant increase in the correlations of average returns occurs among large-capitalization index and non-index stocks in the post-trading period. An increase in correlations is not evident in small-capitalization index or non-index stocks, however. The yearly pattern in the average correlations of stocks tends to mimic the overall trend in index trading; for example, they escalate rapidly from 1985 through 1987. The large-capitalization non-index stocks are an exception.

\section{Implications for Investment Analysis}

There are many implications of this study for practitioners. Take, for example, security analysis. The paradigm works best when it is applied to firms that are subject to large event risks, which alter returns beyond normal expectations. Returns from holding shares of such firms are more sensitive to firm-specific news than to macroeconomic events, they are inherently difficult to analyze, 
and they require close monitoring. Accordingly, they provide analysts with opportunities to make a valuable contribution by applying their special expertise and knowledge. Conversely, stocks with a large systematic risk component, such as those typically used in program trades, are sensitive to macroeconomic events, contain few firm-specific surprises, and provide commensurate payoffs. In an environment of increasing percentage systematic risk, the set of firms to which security analysis applies is in greater flux than one in which percentage systematic risk may be assumed to be stable. Under scrutiny, some firms may be eliminated from the set, and others added.

Senchack and Martin's study has something to say about beta risk, whose estimates are fraught with many perils. One is the estimation process, which is very sensitive to the time interval selected. Given the presence of the hypothesized impact of index futures and options trading, the proper period over which to estimate betas and the time interval for observing data must be selected more judiciously.

Similarly, various adjustment techniques used to reduce measurement errors, biases, or inefficiencies in beta predictions may also be affected. For example, betas are often adjusted for their tendency to drift toward 1.0. A typical adjustment combines a stock's estimated beta with the average historical beta for its industry. This difficult task is exacerbated when percentage systematic risk tends to increase.

Regardless of which portfolio model is used to obtain the final results, almost all assume that the underlying correlations among stocks are stable. Under ordinary circumstances, this assumption makes most of us uncomfortable. In a world in which the correlations change, as Senchack and Martin's study suggests, the data are even more suspect, and the process more disquieting.

Portfolio optimization minimizes risk, given expected returns, and maximizes expected returns, given risk. Combining assets whose expected returns are not highly correlated is the essence of the process. If the average correlations among stocks typically found in an index-already high-increase, their potential diversification benefits are further diminished. This result has at least two implications. First, the traditional tactic of diversifying across industries to reduce total risk may need to be reconsidered for stocks contained in a major index or those that mimic one. Second, the universe of stocks considered by institutional investors may need to be widened; the traditional set may no longer be sufficient to eliminate nonsystematic risk. 
And then there is sector rotation, the success of which depends on identifying homogeneous clusters of stocks across and within sectors or industries. Clustered stocks are expected to be positively and highly correlated within the group and less highly correlated with other groups. This analysis usually begins with historical relations. If average correlations and percentage systematic risk increase, as the study suggests, stock returns and risk tend to homogenize, and the desired clustering may be obfuscated in the following manner: (1) index futures and options spawn basket trading; (2) systematic risk as a percentage of total risk increases; (3) the tendency of heretofore identifiable groups to move out of phase with one another is disrupted; and (4) new clusters must be generated independent of the old set.

\section{In Conclusion}

To be cautious is often to be wise. This study suggests some ways in which to be sagacious. It offers the sorts of insights forward-looking practitioners require when they question their assumptions. When such microstructure market changes as the use of derivative instruments occur, a much closer scrutiny of those assumptions is needed. The long-run survival of the practicing analyst is at stake. Failure to accommodate to the new modalities, regardless of whether one "likes" them, is the sole ingredient of failure. Senchack and Martin provide the evidence and the inferences for such re-examinations of basic assumptions.

Charles A. D'Ambrosio, CFA The Research Foundation of the Institute of Chartered Financial Analysts 


\section{Introduction}

Recent, profound technological changes affecting financial markets have spawned an explosion in financial innovations. Stock index futures and index options, which were introduced in 1982, are cases in point. The value of the daily trading volume of stock index futures has grown to more than the average daily dollar volume of trading on the New York Stock Exchange (NYSE). In addition, index options are the fastest-growing segment of the options market. By October 1987, index futures volume exceeded twice the NYSE volume, and index options accounted for more than 40 percent of the total options volume.

A significant part of this growing volume involves disciplined and heavily quantitative techniques used to execute synchronous trading. Such activity is variously referred to as "basket," "computer-assisted," "portfolio," or "program" trading.

The NYSE defines a "program trade" as any activity simultaneously involving 15 or more securities. The term originally referred to any institutional trading that involved stocks as a group rather than individually; for example, investing large pension contributions or other cash flows, rebalancing a portfolio by revising its asset allocation, or selling a list of unattractive securities. With the introduction of stock index futures trading, "program trading" now generally refers to portfolios traded as a basket, with the individual issues being stocks in a market index. More specifically, the term has become associated with computerized trading strategies such as stock index arbitrage and portfolio insurance. These strategies usually involve simultaneous trading in cash securities and index futures or options. 
These innovations have attracted considerable research. ${ }^{1}$ Studies of stock index futures have addressed at least three major issues: their hedging potential and the price relation between the cash and futures markets; whether information and market sentiment are transmitted from the futures market to the equity markets; and the market volatility on simultaneous expiration dates of index futures and options contracts, the so-called "triple witching hour."

With regard to the latter, the 1987 stock market crash created controversy over the effect of program trading on equity markets. Critics allege that program trading has increased market volatility by causing sharp, intraday price changes that have little to do with economic or financial fundamentals, thereby eroding confidence in the financial markets. Proponents, on the other hand, contend that any perceived volatility is only temporary and merely reflects an improved and more rapid dissemination of information and trade execution through computer technology. They argue that this technology also facilitates more efficient trading techniques and strategies. One computer trading technique, for example, is used to execute orders rapidly through the NYSE SuperDOT system. Such trading strategies as tactical asset allocation and index arbitrage have also been made possible by computers, which generate execution signals by quickly solving the complex mathematical models that underlie these strategies. Moreover, proponents argue, index futures and options provide additional liquidity and offer a faster, lower-cost alternative for hedging equity market risk.

Another, more subtle issue has received only scant attention. The issue warrants closer study because of its major implications for both financial analysts and money managers. Specifically, the issue is whether the introduction of index futures and options has produced a fundamental change in the systematic risk of the indexes themselves. What about the systematic risk of those stocks contained in the underlying cash-market indexes, especially those index stocks that are common to all of the major indexes and that form the core of any program or portfolio trade? Because the various program trading strategies usually involve buying or selling a basket of stocks within a few minutes-often at the end of a trading day-is it possible that such stocks' price changes have become more related to each other than to non-index stocks' price changes? This study seeks to answer such questions.

\footnotetext{
${ }^{1}$ The References at the end of this study provide a summary of related research.
} 
We hypothesize that the following interrelated events occurred in the post-futures trading period:

- The systematic risk component of the variance (total risk) in returns for the Major Market Index (MMI) and the S\&P 500 Composite Index (S\&P $500)$ increased.

- The systematic risk component of total risk in returns of index stocks increased.

- The covariability among the index stocks' returns increased.

- The systematic risk component and covariability of non-index stocks' returns did not increase.

To understand why these events may have occurred, consider an extreme example-the "cascade theory" - which states that "mechanical, price-insensitive selling" by institutions using portfolio insurance strategies contributes significantly to any drop in stock prices (Report of the Presidential Task Force on Market Mechanisms, p. v). According to this theory, in an effort to hedge their market risk exposure institutions quickly sell index futures rather than liquidate stock positions. The selling pressure tends to decrease futures contract prices relative to the equivalent cash-market index. The decline induces index arbitragers to purchase futures contracts, undervalued in their view, and sell (short) the underlying stocks. This arbitrage activity thus transmits the initial bearish impact of portfolio insurance selling to the stock market. This selling pressure in the cash market causes cash prices to decline, which triggers further selling by portfolio insurers of futures contracts that is again transmitted to the cash market by arbitrageurs, and so on.

\section{Description of the Study}

We began by investigating the daily systematic risk behavior of the MMI and S\&P 500 for the $1980-87$ period. Specifically, systematic risk as a percentage of total risk was analyzed before and after the introduction of index futures and options trading. This focus allowed us to determine whether there had been a structural shift in the relation of the indexes.

Next, we studied the systematic risk of five individual stock samples. One sample consisted of all 20 stocks in the MMI, two samples were subgroups of S\&P 500 stocks, and the other two were composed of stocks not in the indexes but comparable in size to the S\&P 500 samples. These non-index stocks were 
used as control groups because they were not likely to be subject to program trading influences.

We selected the MMI to test the hypotheses because little research has focused on the various MMI contracts, and more importantly, because MMI stocks are major components of all index futures or option contracts and all have traded equity options. The MMI also contains stocks that represent the largest U.S. corporations and are widely held by institutional investors. Thus, they form an integral part of any arbitraged or insured portfolio. Fundamental changes in the stocks' price behavior are relatively more important to investors than changes in smaller stocks. ${ }^{2}$ The MMI also seems to be a more easily arbitraged or insured portfolio because fewer stocks are involved. The fact that MMI is a price-weighted rather than a value-weighted index, however, complicates the appropriate hedge ratio in any arbitrage or hedging activity.

The S\&P 500 and two 20 -stock subgroups were selected because S\&P 500 futures are the most actively traded contract. As noted, two control samples were constructed from comparable stocks not in the S\&P 500, because they are not likely to be influenced by portfolio trading.

Because one of the study's purposes was to document whether synchronous trading of index stocks affected their covariation, the statistical interrelation of the indexes and the five stock samples' returns were then examined over different time segments. First, we studied three subperiods representing pre-futures, transition, and post-futures trading periods. Second, the data were analyzed by calendar years. Third, because program trading reached its zenith in 1987, most of that year was analyzed. The year of the crash was examined by partitioning the trading days into those with high-intensity versus those with low-intensity program trading activities.

${ }^{2}$ On December 31, 1987, for instance, the total market values of the following indexes (in billions of dollars) were:

$\begin{array}{lll}\text { MMI } & \$ 456 \quad \text { NYSE Composite } & \$ 2,171\end{array}$

S\&P $500 \quad \$ 1,736 \quad$ Wilshire $5000 \quad \$ 2,315$.

The 20 MMI stocks were, respectively, 26 and 20 percent of the S\&P 500 's and Wilshire 5000 Equity Index's market values. 


\section{Analytical Framework of the Study}

\section{The Data and Sample Design}

Four market indexes and five samples of stocks were used in the analysis. The four indexes are (1) the CRSP equally weighted (EWCRSP), (2) the CRSP value-weighted (VWCRSP), (3) the Standard \& Poor's 500 composite (S\&P 500), and (4) the Major Market Index (MMI). The two CRSP indexes were used as proxies for the market. The MMI and S\&P were analyzed for changes in systematic risk.

The data for the first three indexes were obtained from the 1987 CRSP Daily Return File. The MMI's daily returns were calculated from the closing prices provided by the Chicago Board of Trade. The daily returns (with dividends) for the individual index and non-index stocks were obtained from the CRSP Daily Return File.

The CRSP equally weighted market index was selected because it is less susceptible to the influence of program trading than a value-weighted index. That is, it is less sensitive to the price behavior of larger firms that dominate the composition of index futures. Both CRSP indexes were used because the MMI is a price-weighted index, and it is not clear which market proxy is more representative of the weighting scheme inherent in the MMI. A priceweighted index is disproportionately influenced by higher-priced stocks. The MMI may behave more like a value-weighted index because large MMI firms also tend to be higher-priced stocks.

The five stock samples included one sample containing each stock in the MMI, and four non-MMI stock samples, each containing 20 issues. The four non-MMI stock samples consisted of two 20-stock samples from the S\&P 500 and two 20-stock samples not in the S\&P 500. The two sets are called index 
and non-index stocks, respectively. A total of 100 individual stocks were included in the samples. The following summarizes the sampling process.

Our first sample of index stocks, the 20 component stocks of the MMI, are larger stocks listed on the NYSE. All are contained in the S\&P 500 Index, and 17 are in the Dow Jones Industrial Average.

Of the four non-MMI samples, two consist of stocks contained in the S\&P 500 Index, and two consist of non-S\&P 500 stocks. The first sample includes 20 larger S\&P 500 stocks as of December $31,1984,{ }^{1}$ and the second sample includes 20 smaller S\&P 500 Index stocks. These stocks were randomly selected from the lowest quartile of market value. ${ }^{2}$ The third and fourth samples consist of 20 stocks not in either index. Each of the latter samples was randomly selected from stocks listed on either the NYSE or the American Stock Exchange (ASE). One sample was comparable in size to the larger stocks contained in the S\&P 500 sample of stocks; the other sample was comparable to the smaller sample drawn from the S\&P $500 .^{3}$

The subperiod analysis allows us to determine the systematic risk changes at various significant dates. The returns of the market indexes and the five samples are then divided into three subperiods. The subperiods, determined by the initial trading date of both index futures and of the MMI futures contract, are as follows: (1) January 2, 1980, to January 31, 1982 (pre-futures period); (2) February 1, 1982, to July 23, 1984 (transition period); and (3) July 24, 1984, to October 9, 1987 (post-futures period). This subdivision was used because there was a persistent element of mispricing between the futures and cash markets through 1984. The declines in S\&P 500 futures mispricing from May

\footnotetext{
${ }^{1}$ With one exception, Wal-Mart, these sample firms were members of the S\&P 500 Index for the entire period (1980-87). Wal-Mart became a member of the S\&P 500 in June 1982.

${ }^{2}$ All but four of these sample firms were members of the S\&P 500 for the entire 1980-87 period. Brown Forman Distillers joined the index in June 1982, and three firms (Coastal Corp., E.G.\&G., and Great Northern Nekoosa) were added in December 1983.

${ }^{3}$ One potential problem with our selection criteria is the manner in which S\&P 500 stocks are selected. Because the S\&P index contains 400 industrials and only 20 transportation, 40 utility, and 40 financial stocks, large-capitalization non-index stocks may tend to be either utility or financial stocks. For instance, our large-capitalization non-index sample contains 11 utility and 4 financial stocks. Similarly, the small-capitalization non-index stock sample contains nine utilities and one financial institution. Whereas this should increase the correlation among the non-index stocks, it is not clear $a$ priori the extent to which bias is introduced into the analysis of program trading.
} 
1982 through September 1987, as measured by the range and average monthly difference between the largest premium and largest discount, are shown in the footnote below. ${ }^{4}$

The statistics on discounts on index futures and open interest on futures and options suggest that program trading was not a significant factor until 1984, even though trading in index futures began in February 1982, with the Value Line Composite Index, and most index options began in early 1983. That is to say, growth in index futures and options volume, especially open interest, did not occur until after mid-1984, when institutional investors apparently became a major factor in these markets. Nevertheless, because index trading may have influenced the behavior of index stocks in the transition period before MMI futures trading began in July 1984, this period was treated separately.

The subperiod surrounding and subsequent to the October 19, 1987, market crash was excluded from the above analysis for two reasons: (1) covariability measures are very sensitive to extreme values, such as those on the day of the crash and surrounding trading days, and (2) all program trading through the end of 1987 was essentially suspended following the crash. Nonetheless, because 1987 was such an unusual year for financial markets, we analyzed it separately and in more detail. We did this by dichotomizing the period into days of high and low program trading intensity.

${ }^{4}$ Futures mispricing:

$\begin{array}{lcccc}\text { Year } & \begin{array}{c}\text { Largest Premium } \\ \text { to Fair Value }\end{array} & \begin{array}{c}\text { Largest Discount } \\ \text { to Fair Value }\end{array} & \text { Range } & \begin{array}{c}\text { Average Monthly } \\ \text { Difference }\end{array} \\ 1982 \text { (June) } & 2.59 \% & -4.14 \% & 6.73 \% & \\ 1983 & 1.39 & -1.52 & 2.91 & 2.85 \% \\ 1984 & 2.42 & -0.55 & 2.97 & 1.33 \\ 1985 & 1.70 & -0.75 & 2.45 & 1.46 \\ 1986 & 1.01 & -1.17 & 2.18 & 1.19 \\ 1987 \text { (September) } & 0.74 & -0.88 & 1.62 & 1.19 \\ \end{array}$

Source: Zurack, M.A. and W.W. Toy. 1987. "Stock Index Trading: A Five-Year Review through September 1987." Goldman, Sachs \& Co. (October). 


\section{Measuring Percentage Systematic Risk}

The concepts of systematic and nonsystematic risks denote that the return on an asset depends on a factor(s) that is systematically related to the market in which the asset is traded and to a factor(s) that is unique to that asset. One way to analyze the relation is to use the market model, which is:

$$
R_{i, t}=a_{i}+b_{i} R_{M, t}+e_{i, t},
$$

where

$a_{i}$ and $b_{i}$ are the $i^{\text {th }}$ market index's or stock's intercept and systematic risk parameters,

$R_{i, t}$ is the daily return on the $i^{\text {th }}$ market index or stock for day $t$;

$R_{M, t}$ is the daily return on the equally weighted or value-weighted CRSP index (with dividends) for day $t$; and

$e_{i, t}$ is the residual error term for day $t$.

The CRSP indexes are the market proxies in our analysis. The marketrelated risk component is indexed by the $b_{i}$ (beta) term. The non-marketrelated risk component depends on the last term, $e_{i, t}$. This residual contains all of the factors not contained in beta.

Total risk is defined in the traditional way as the variance of the index or stock returns, $\sigma^{2}\left(R_{i}\right)$ :

$$
\sigma^{2}\left(R_{i}\right)=b_{i}^{2} \sigma^{2}\left(R_{M}\right)+\sigma^{2}\left(e_{i}\right),
$$

where $\sigma^{2}\left(R_{M}\right)$ and $\sigma^{2}\left(e_{i}\right)$ are the variances of the market index returns and stock's nonsystematic returns, respectively. The first and second terms on the right side of the equation are, respectively, the systematic and nonsystematic risk components. This equation may be rewritten in terms of percentages by dividing both sides by $\sigma^{2}\left(R_{i}\right)$, or

$$
100 \%=\left(r_{i}^{2}+\frac{\sigma^{2}\left(e_{i}\right)}{\sigma^{2}\left(R_{i}\right)}\right) \times 100,
$$

where the first term on the right-hand side is now the percentage of total risk resulting from systematic risk. This term is equal to the coefficient of determination from the market model, and it measures the percentage of total 
variation in an asset's return explained by the variation in market returns. The second term in the equation is the proportion of total risk due to the nonsystematic variation in the MMI, the S\&P 500 , or the individual stocks' returns; it measures the percentage of total variation in return not explained by the variation in returns on the market. This relation suggests that one measure of the impact of program trading on stock behavior is a pairwise comparison of $r_{i}^{2}$ over the various subperiods.

To test the statistical significance of any changes in pre- and post-futures systematic risk, the square root of each index's and stock's subperiod $r^{2}$ is taken. This procedure converts each into a simple correlation coefficient. A test of the equality of correlations is then conducted for the pre- and postfutures periods. ${ }^{5}$

The next set of tests involves the return correlations among the individual index and non-index stocks. Each stock sample's correlation matrix is estimated for every subperiod. For reporting purposes, average correlations across each sample are estimated for the three subperiods and for each calendar year. One way to measure the impact of program trading on stock behavior is to compare $r^{2}$ 's from one period to the next.

\section{Measurement of the Covariability of Individual Stocks}

To test the equality of correlation matrices themselves, both pairwise and multiple-period comparisons are conducted across each subperiod and calendar year for each stock sample. The null hypothesis of equal correlation matrices is tested by using the Box-M statistic, ${ }^{6}$

$$
\text { Box-M }=(1-\alpha) M \text {, }
$$

\footnotetext{
${ }^{5}$ Because the distribution of a sample correlation tends to normality so slowly, our test of equality of correlation coefficients first involves transforming the sample correlation, $\rho_{i t}$, by $z_{i j}=1 / 2 \log \left[\left(1+\rho_{i j}\right) /\left(1-\rho_{i j}\right)\right]$, which is more closely normally distributed with a variance approximately equal to $1 /(n-3)$, where $j$ refers to the pre-futures, transition, and post-futures subperiods, and where $n$ equals the number of observations (trading days) in time period $t$.

${ }^{6}$ See Morrison (1976) and Box (1949). For a recent example of its application, see Cho and Taylor (1987).
} 
where

$$
\alpha=\frac{\left(2 p^{2}+3 p-1\right)}{6(p+1)(q-1)}\left(\sum_{i=1}^{q} \frac{1}{n_{i}-1}-\frac{1}{N-q}\right),
$$

and

$$
\mathrm{M}=\sum_{i=1}^{q}\left(n_{i}-1\right) \ln \left|S^{-1} S_{i}\right| S=\frac{1}{N-q} \sum_{i=1}^{q}\left(n_{i}-1\right) S_{i}
$$

has a $\chi^{2}$ distribution with $d f_{1}=\frac{p(p+1)(q-1)}{2}$ degrees of freedom. Here $S_{i}$ is the $i^{\text {th }}$ period correlation matrix, $p$ is the number of variables in the matrix, $q$ is the number of correlation matrices being compared, and $N$ is equal to $\sum_{i=1}^{q} n_{i}$, where $n_{i}$ is the number of observations for the $i^{\text {th }}$ sample period.

The chi-squared approximation appears to be good if $p$ and $q$ do not exceed four or five, and each $n_{i}$ is 20 or more. For greater $p$ and $q$ and small $n_{i}$, an F-approximation is more accurate and should be used. To obtain the F-approximation further calculations are necessary. Define $\beta$ as

$$
\beta=\frac{(p-1)(p+2)}{6(q-1)}\left(\sum_{i=1}^{q} \frac{1}{\left(n_{i}-1\right)^{2}}-\frac{1}{(N-q)^{2}}\right) .
$$

If $\beta-\alpha^{2}$ is positive, then

$$
d f_{2}=\frac{d f_{1}+2}{\beta-\alpha^{2}}
$$

and

$$
\mathrm{F}=\frac{\mathrm{M}\left(1-\alpha-\left(d f_{1} / d f_{2}\right)\right)}{d f_{1}}
$$


has an $\mathrm{F}$ distribution with $d f_{1}$ and $d f_{2}$ degrees of freedom. If $\beta-\alpha^{2}$ is negative, then use the following:

$$
d f_{2}=\frac{d f_{1}+2}{\alpha^{2}-\beta}
$$

and

$$
\mathrm{F}=\mathrm{M}\left(\frac{d f_{2}}{d f_{1}}\right)\left(\frac{1}{\frac{d f_{2}}{1-\alpha+\left(2 / d f_{2}\right)}-\mathrm{M}}\right)
$$

has an $\mathrm{F}$ distribution with $d f_{1}$ and $d f_{2}$ degrees of freedom.

The testing is performed first on all correlation matrices together, and then on each pair. For the paired comparisons, the above equations are the same, but $q$ is set equal to 2 . In addition to testing the equality of the pre- and post-futures matrices, a test of equality is done for each of the calendar years 1980-87. This procedure provides insights into whether any altered systematic price behavior is symptomatic of the entire post-futures period or is a more recent phenomenon associated with increased program trading activity. 


\section{Changes in Percentage Systematic Risk}

This chapter presents evidence of the changes in the percentage systematic risk. The comparisons are presented for the MMI and S\&P 500 indexes and then for the individual index and non-index stocks.

\section{The MMI and S\&P 500 Indexes}

Table 1 compares the level and percentages of systematic risk for the MMI and S\&P 500 indexes for the pre-futures, transition, and post-futures trading periods. Panel A shows that the MMI's beta is less than one in the pre-futures period, but it shifts upward dramatically in the post-futures period. ${ }^{1}$ More important to this study, however, the MMI's percentage systematic risk and correlation with the market proxies also increased dramatically in the transition and post-futures periods, although the latter measures were somewhat lower than the former.

\footnotetext{
${ }^{1}$ To test for the significance of the changes in the level of systematic risk, a linear switching regression model was constructed that allows us to determine whether the model parameters shifted following futures trading in the MMI; that is,

$$
R_{i, t}=a_{i}+a_{i}^{\prime} D+b_{i} R_{M, t}+b_{i}^{\prime}\left(D \times R_{M, t}\right)+e_{i, t} .
$$

where $D$ is a dummy variable that assumes the value of zero for each day during the pre-futures trading period and a value of one for the transition or post-futures period. In this model, $a_{i}^{\prime}$ and $b_{i}^{\prime}$ reflect the changes, respectively, in the intercept and slope (level of systematic risk) parameters after January 1982 . Thus, if $b_{i}^{\prime}$ is found to differ significantly from zero, we may reject the hypothesis that no change in this parameter occurred subsequent to futures trading on the MMI. The four changes in the beta coefficients for the MMI and S\&P 500 versus the EWCRSP and VWCRSP indexes in the transition and post-futures trading periods in Table 1 were found to be statistically different from zero at the 1 percent level of significance.
} 
The results reported in Panel B of Table 1 indicate that the S\&P 500's beta also increased, but its returns were more highly correlated with both market proxies than were those of the MMI. Its overall relation to the market proxies remained essentially unaltered when compared to the VWCRSP and was somewhat higher when compared to the EWCRSP. This finding suggests that any changes in the level and percentage of systematic risk may be limited to

\section{TABLE 1}

\section{Comparison of the MMI and S\&P 500 Indexes' Market Model Parameters*}

$\begin{array}{cccc} & \text { Level of } & \text { Percentage } & \\ \text { Time Period } & \text { Systematic } & \text { Systematic } & \text { Correlation } \\ & \text { Risk (Beta) } & \text { Risk }\left(r^{2}\right) & \text { Coefficient }\end{array}$

A. MMI vs.

$\begin{array}{lllll}\text { EWCRSP: } & \text { Pre-Futures } & 0.837^{\mathrm{a}} & 0.479 & 0.692 \\ & \text { Transition } & 1.126^{\mathrm{a}} & 0.617 & 0.785^{\mathrm{b}} \\ & \text { Post-Futures } & 1.124^{\mathrm{a}} & 0.588 & 0.767^{\mathrm{b}} \\ & & & & \\ \text { VWCRSP: } & \text { Pre-Futures } & 0.955^{\mathrm{a}} & 0.760 & 0.872 \\ & \text { Transition } & 1.099^{\mathrm{a}} & 0.886 & 0.941^{\mathrm{b}} \\ & \text { Post-Futures } & 1.127^{\mathrm{a}} & 0.880 & 0.938^{\mathrm{b}}\end{array}$

B. S\&P 500 vs.

$\begin{array}{lllll}\text { EWCRSP: } & \text { Pre-Futures } & 0.934^{\mathrm{a}} & 0.715 & 0.846 \\ & \text { Transition } & 1.157^{\mathrm{a}} & 0.767 & 0.876^{\mathrm{b}} \\ & \text { Post-Futures } & 1.155^{\mathrm{a}} & 0.742 & 0.862^{\mathrm{b}} \\ & & & & \\ \text { VWCRSP: } & \text { Pre-Futures } & 0.992^{\mathrm{a}} & 0.986 & 0.993 \\ & \text { Transition } & 1.069^{\mathrm{a}} & 0.989 & 0.994 \\ & \text { Post-Futures } & 1.091^{\mathrm{a}} & 0.987 & 0.994\end{array}$

\footnotetext{
* Using equally weighted (EWCRSP) and value-weighted CRSP (VWCRSP) indexes as market proxies.

a Statistically significant beyond the 1 percent level.

b A pairwise comparison between the pre-futures versus the transition and the post-futures correlations indicates that both two-period correlation comparisons are statistically different from each other beyond the 1 percent level of significance.

Pre-Futures: January 2, 1980 to January $31,1982$.

Transition: $\quad$ February 1,1982 to July 23,1984

Post-Futures: July 24, 1984 to October 9, 1987.
} 
the larger companies contained in such market indexes as the MMI. It also indicates that the MMI's behavior is more akin to a market index that is value-weighted than to one that is equally weighted.

\section{The Individual Index and Non-index Stocks}

Tables 2 through 6 present information on the percentage systematic risk for the five samples of stocks. Because the results are very similar when either

\section{TABLE 2}

\section{Percentage Systematic Risk of the Individual MMI Stocks*}

\section{Company}

American Express

AT\& $T^{b}$

Chevron

Coca-Cola

Dow Chemical

DuPont

Eastman Kodak

Exxon

General Electric

General Motors

IBM

International Paper

Johnson \& Johnson

Merck \& Co.

Minn. Mining \& Mfg.

Mobil

Philip Morris

Proctor \& Gamble

Sears

USX

\begin{tabular}{ccc} 
& Time Period \\
\hline Pre-Futures & Transition & Post-Futures \\
$r^{2}$ & $r^{2}$
\end{tabular}

0.300

0.415

0.415

0.175

0.442

0.207

0.382

0.324

0.340

0.459

0.426

0.274

0.391

0.322

0.275

0.230

0.323

0.303

0.282

0.226

0.237

0.188
0.271

0.348

0.304

0.375

0.440

0.326

0.392

0.520

0.487

0.621

0.335

0.306

0.305

0.495

0.357

0.317

0.294

0.506

0.191
0.354

0.203

0.400

0.411 .

0.423

0.299

0.304

0.554

0.347

0.429

0.304

0.378

0.366

0.435

0.176

0.389

0.343

0.430

0.099

* Using the value-weighted CRSP index as a market proxy.

all F-statistics for the individual regressions were significant beyond the 1 percent level.

AT\&T, which resulted from a court-ordered breakup of the Bell System, received about 23 percent of the former company's assets. Therefore, post-divestiture data after 1983 are not comparable to the predivestiture data.

Pre-Futures: January 2, 1980 to January $31,1982$.

Transition: $\quad$ February 1, 1982 to July 23, 1984 .

Post-Futures: July 24, 1984 to October 9, 1987. 
the equally weighted or value-weighted indexes are used as market proxies, only those explained by the VWCRSP index are reported.

Table 2 reports the results of the MMI stocks and shows that the systematic risk of most of them increased in the transition and post-futures periods when compared to the pre-futures period. The systematic risks of 16 of the $20 \mathrm{MMI}$ stocks increased from the pre-futures to transition period, whereas 13 increased from the pre- to post-futures period. The systematic risk of only nine stocks was higher in the post-futures period when compared to the transition period.

\section{TABLE 3}

\section{Percentage Systematic Risk of the Largest Non-MMI Stocks in the S\&P 500*}

\begin{tabular}{|c|c|c|c|}
\hline \multirow{2}{*}{ Company } & \multicolumn{3}{|c|}{ Time Period ${ }^{\mathrm{a}}$} \\
\hline & $\begin{array}{c}\text { Pre-Futures } \\
r^{2}\end{array}$ & $\underset{r^{2}}{\text { Transion }}$ & $\begin{array}{c}\text { Post-Futures } \\
r^{2}\end{array}$ \\
\hline Abbott Labs & 0.231 & 0.283 & 0.457 \\
\hline American Home Products & 0.249 & 0.280 & 0.367 \\
\hline Amoco & 0.458 & 0.362 & 0.213 \\
\hline Atlantic-Richfield & 0.464 & 0.331 & 0.162 \\
\hline Boeing & 0.314 & 0.253 & 0.239 \\
\hline Bristol-Myers & 0.322 & 0.336 & 0.437 \\
\hline Digital Equipment & 0.423 & 0.357 & 0.350 \\
\hline Dun \& Bradstreet & 0.119 & 0.164 & 0.448 \\
\hline Ford Motor & 0.169 & 0.449 & 0.367 \\
\hline GTE & 0.182 & 0.359 & 0.367 \\
\hline Hewlett-Packard & 0.421 & 0.422 & 0.342 \\
\hline Lilly (Eli) & 0.275 & 0.177 & 0.353 \\
\hline McDonald's & 0.281 & 0.345 & 0.384 \\
\hline Pepsico & 0.180 & 0.259 & 0.342 \\
\hline Pfizer & 0.291 & 0.282 & 0.381 \\
\hline RJR-Nabisco & 0.287 & 0.260 & 0.309 \\
\hline Royal Dutch Petroleum & 0.321 & 0.314 & 0.196 \\
\hline Texaco & 0.381 & 0.297 & 0.077 \\
\hline Wal-Mart & 0.107 & 0.167 & 0.404 \\
\hline Westinghouse & 0.405 & 0.485 & 0.439 \\
\hline \multicolumn{4}{|c|}{$\begin{array}{l}\text { * Using the value-weighted CRSP index as a market proxy. } \\
\text { all F-statistics for the individual regressions were significant beyond the } 1 \text { percent level. }\end{array}$} \\
\hline \multirow{3}{*}{$\begin{array}{l}\text { Pre-Futures: } \\
\text { Transition: } \\
\text { Post-Futures: }\end{array}$} & lary $31,1982$. & & \\
\hline & y 23,1984 & & \\
\hline & 1987. & & \\
\hline
\end{tabular}


Tables 3 and 4 report on the other two index-related samples. Twelve stocks in each sample had higher systematic risk in the transition versus pre-futures periods, and about half in the post- versus pre-futures periods. Only eight of the smaller index stocks had higher systematic risk in the post-futures period when compared to the transition period.

Tables 5 and 6 show that larger non-index stocks increased more than any stock sample in relation to the market. The smaller non-index stocks more closely mimicked the smaller S\&P 500 stocks.

\section{TABLE 4}

\section{Percentage Systematic Risk of Smaller Index Stocks in the S\&P 500*}

\section{Company}

Ahmanson, H.F.

Amax Inc.

Armstrong World Indus.

Bethlehem Steel

Black \& Decker

Brown-Forman Distillers

Coastal Corp.

Combustion Engineering

Consolidated Freightways

Data General

E.G. \& G. Inc.

Firestone Tire \& Rubber

Great Northern Nekoosa

Great Western Financial

Harris Corp.

INTERCO, Inc.

Louisiana Land \& Expl.

Owens-Corning-Fiberglas

Polaroid

Williams Cos.

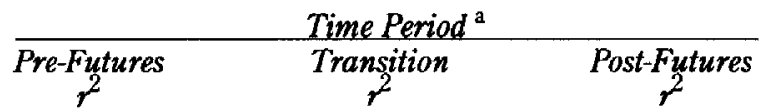

0.115

0.104

0.152

0.207

0.166

0.047

0.260

0.270

0.036

0.300

0.276

0.137

0.214

0.218

0.244

0.088

0.334

0.139

0.192

0.233
0.238

0.298

0.181

0.277

0.170

0.080

0.195

0.196

0.115

0.264

0.228

0.177

0.083

0.274

0.223

0.136

0.266

0.221

0.234

0.165
0.261

0.098

0.270

0.105

0.146

0.108

0.112

0.141

0.227

0.180

0.215

0.204

0.268

0.308

0.165

0.173

0.131

0.204

0.195

0.060

* Using the value-weighted CRSP index as a market proxy.

a All F-statistics for the individual regressions were significant beyond the 1 percent level.

Pre-Futures: January 2, 1980 to January $31,1982$.

Transition: $\quad$ February 1, 1982 to July 23, 1984.

Post-Futures: July 24, 1984 to October 9, 1987. 


\section{TABLE 5}

\section{Percentage Systematic Risk of the Largest Non-index Stocks*}

\begin{tabular}{|c|c|c|c|}
\hline \multirow[b]{2}{*}{ Company } & \multicolumn{3}{|c|}{ Time Period ${ }^{\mathrm{a}}$} \\
\hline & $\underset{r^{2}}{\text { Pre-Futures }}$ & $\underset{r^{2}}{\text { Transition }}$ & Post-Futures \\
\hline Affiliated Publications & 0.041 & 0.000 & 0.077 \\
\hline Allegheny Power System & 0.127 & 0.091 & 0.174 \\
\hline Ashland Oil & 0.117 & 0.107 & 0.062 \\
\hline Carolina P\&L & 0.106 & 0.093 & 0.154 \\
\hline Centel Corp. & 0.100 & 0.102 & 0.077 \\
\hline Contel Corp. & 0.107 & 0.174 & 0.157 \\
\hline First Fidelity Bancorp & 0.063 & 0.092 & 0.099 \\
\hline FNMA & 0.148 & 0.291 & 0.310 \\
\hline General Public Utilities & 0.032 & 0.068 & 0.113 \\
\hline Loews Corp. & 0.261 & 0.239 & 0.273 \\
\hline Marion Labs & 0.132 & 0.172 & 0.241 \\
\hline Northeast Utilities & 0.038 & 0.047 & 0.200 \\
\hline Pacific Corp. & 0.067 & 0.126 & 0.172 \\
\hline Pennsylvania Power & 0.054 & 0.083 & 0.141 \\
\hline Pinnacle West Capital & 0.055 & 0.069 & 0.165 \\
\hline Potomac Electric Power & 0.079 & 0.066 & 0.113 \\
\hline $\begin{array}{l}\text { San Diego Gas \& Electric } \\
\text { Security Pacific }\end{array}$ & 0.033 & 0.079 & 0.194 \\
\hline Security Pacific & 0.142 & 0.163 & 0.210 \\
\hline Union Electric & 0.033 & 0.055 & 0.156 \\
\hline Washington Post & 0.024 & 0.097 & 0.097 \\
\hline \multicolumn{4}{|c|}{$\begin{array}{l}\text { * Using the value-weighted CRSP index as a market proxy. } \\
\text { All F-statistics for the individual regressions were significant beyond the } 1 \text { percent level. }\end{array}$} \\
\hline \multicolumn{4}{|c|}{$\begin{array}{ll}\text { Pre-Futures: } & \text { January 2, } 1980 \text { to January } 31,1982 . \\
\text { Transition: } & \text { February 1, 1982 to July 23,1984. }\end{array}$} \\
\hline \multicolumn{4}{|c|}{$\begin{array}{ll}\text { Transition: } & \text { February 1, } 1982 \text { to July } 23,1984 . \\
\text { Post-Futures: } & \text { July } 24,1984 \text { to October } 9,1987 .\end{array}$} \\
\hline
\end{tabular}

Table 7 summarizes the data contained in Tables 2 through 6 . It presents the average percentage systematic risk for the five samples over the three subperiods. The two samples of larger index stocks and the larger non-index stock samples showed a higher degree of systematic risk following the introduction of index futures and options. The larger index stocks had a higher percentage systematic risk than the other stocks. Regardless of which market proxy was used, the MMI's systematic risk tended to fall in the post-futures period, but it dropped to a level above that of the pre-futures period. The systematic risk of both the large non-MMI stocks and larger non-index stocks 


\section{TABLE 6}

\section{Percentage Systematic Risk of Smaller Non-index Stocks*}

Company

Alco Standard

Ames Dept. Stores

Analog Devices

Arkla Inc.

Boston Edison

Central Illinois P.S.

Delmar P\&L

Harsco Corp.

Idaho Power

IPALCO Enterprises

Irving Bank

Kansas City P\&L

Kansas P\&L

Murphy Oil

Olin Corp.

Premier Industrial

Rochester Gas \& Electric

Rorer Group

Staley Continental

Telex Corp.

\begin{tabular}{ccc}
\multicolumn{3}{c}{ Time Period } \\
\hline$r^{\text {Pre-Futures }}$ & Transition & Post-Futures \\
$r^{2}$ & & $r^{2}$
\end{tabular}
0.019
0.095
0.148
0.172
0.023
0.039
0.097
0.029
0.045
0.069
0.063
0.091
0.074
0.326
0.205
0.050
0.027
0.084
0.228
0.211

0.069

0.117

0.178

0.111
0.121

0.050

0.083

0.081

0.053

0.090

0.082

0.139

0.051

0.094

0.222

0.201

0.054

0.037

0.129

0.131

0.267
0.083

0.172

0.031

0.086

0.133

0.103

0.052

0.102

0.200

0.061

0.092

0.104

0.113

0.189

0.081

0.070

0.035

0.127

0.128

* Using the value-weighted CRSP index as a market proxy.

a All F-statistics for the individual regressions were significant beyond the 1 percent level.

Pre-Futures: January 2, 1980 to January $31,1982$.

Transition: $\quad$ February 1,1982 to July $23,1984$.

Post-Futures: July 24, 1984 to October $9,1987$.

steadily increased over time, however. The largest percentage increase occurred in the non-index stocks. In contrast, the correlations among the smaller index and non-index stock returns tended to increase in the transition period. Then they fell in the post-futures period to a level lower than that of the pre-futures period. This finding is consistent with the notion that the effect of program trading on systematic risk is restricted to larger stocks. 


\section{TABLE 7}

\section{Average Percentage Systematic Risk for the Five Individual Stock Samples}

\begin{tabular}{|c|c|c|c|c|}
\hline \multirow[b]{2}{*}{ Stock Sample } & \multirow[b]{2}{*}{$\begin{array}{l}\text { Market } \\
\text { Index* }\end{array}$} & \multicolumn{3}{|c|}{ Time Period } \\
\hline & & $\begin{array}{c}\text { Pre-Futures } \\
r^{2}\end{array}$ & $\underset{r^{2}}{\text { Transition }}$ & $\begin{array}{c}\text { Post-Futures } \\
r^{2}\end{array}$ \\
\hline \multirow[t]{2}{*}{ MMI stocks } & EW & 0.206 & 0.267 & 0.234 \\
\hline & VW & 0.305 & 0.380 & 0.353 \\
\hline \multirow{2}{*}{$\begin{array}{l}\text { Largest non-MMI } \\
\text { S\&P Index stocks }\end{array}$} & EW & 0.215 & 0.231 & 0.245 \\
\hline & VW & 0.294 & 0.309 & 0.332 \\
\hline \multirow[t]{2}{*}{ Smaller S\&P stocks } & $\mathrm{EW}$ & 0.175 & 0.189 & 0.161 \\
\hline & VW & 0.187 & 0.201 & 0.179 \\
\hline \multirow[t]{2}{*}{ Largest non-index stocks } & EW & 0.103 & 0.114 & 0.156 \\
\hline & VW & 0.088 & 0.111 & 0.159 \\
\hline \multirow[t]{2}{*}{ Smallest non-index stocks } & $\mathrm{EW}$ & 0.120 & 0.117 & 0.112 \\
\hline & VW & 0.105 & 0.112 & 0.104 \\
\hline \multicolumn{5}{|c|}{$\begin{array}{ll}\text { * } & \text { EW and VW refer to the equally weighted and va } \\
\text { Pre-Futures: } & \text { January } 2,1980 \text { to January } 31,1982 . \\
\text { Transition: } & \text { February } 1,1982 \text { to July } 23,1984 . \\
\text { Post-Futures: } & \text { July } 24,1984 \text { to October } 9,1987 .\end{array}$} \\
\hline
\end{tabular}




\section{Changes in the Covariability of Individual Stocks}

We next analyzed changes in the covariability of individual stocks. We looked at average correlation coefficients by subperiod for each stock's returns with the other stocks' returns within and across the respective samples. This analysis was intended to determine whether-and the extent to which-the individual stocks were more or less highly related to each other as a result of the introduction of futures or options trading. In general, the behavior of individual correlations within a sample, as well as across samples, differed significantly from period to period. ${ }^{1}$

\section{Subperiod Comparisons}

Tables 8 through 12 indicate that the average correlations of most index-related stocks were higher in the transition and post-futures periods than in the pre-futures period. The MMI stocks and smaller index stocks experienced the largest and smallest number of increases, respectively. For the transition period, however, the average correlations for most MMI and smaller index stocks declined. The non-index stocks exhibited almost the opposite pattern: Most average correlations dropped in the transition period but increased in the post-futures period. Moreover, the correlations of all of the larger non-

\footnotetext{
${ }^{1}$ The Box-M statistics for a simultaneous comparison of each sample's correlation matrices reject the hypothesis of identical correlation matrices across all three subperiods at the 1 percent level of significance. For each subperiod and each stock sample, a 20 by 20 diagonal correlation matrix is estimated, where the diagonal elements are equal to one and the off-diagonal elements are the individual correlation coefficients of each stock with every other stock in the sample. The Box-M (and Box-F) test of equality then compares simultaneously the entire correlation matrix with all its individual correlations for the pre-futures, transition, and post-futures periods.
} 


\section{TABLE 8}

\section{Average Correlation Coefficients of the MMI Stocks}

Company

American Express

AT\& $T$ *

Chevron

Coca-Cola

Dow Chemical

DuPont

Eastman Kodak

Exxon

General Electric

General Motors

IBM

International Paper

Johnson \& Johnson

Merck \& Co.

Minn. Mining \& Mfg.

Mobil

Philip Morris

Proctor \& Gamble

Sears

USX

$\begin{array}{ll}\text { Time Period } & \text { Transition }\end{array}$

0.346

0.250

0.315

0.277

0.377

0.366

0.390

0.338

0.405

0.334

0.399

0.319

0.333

0.304

0.359

0.275

0.351

0.295

0.325

0.267
0.391

0.332

0.357

0.377

0.388

0.419

0.379

0.370

0.459

0.441

0.494

0.364

0.355

0.334

0.447

0.352

0.358

0.356

0.442

0.255
0.373

0.372

0.292

0.388

0.385

0.404

0.352

0.360

0.470

0.371

0.386

0.356

0.377

0.374

0.429

0.280

0.367

0.373

0.393

0.180

* AT\&T, which resulted from a court-ordered breakup of the Bell System, received about 23 percent of the former company's assets. Therefore, post-divestiture data after 1983 are not comparable to the predivestiture data.

Pre-Futures: January 2, 1980 to January $31,1982$.

Transition: $\quad$ February 1,1982 to July 23,1984 .

Post-Futures: July 24, 1984 to October 9, 1987.

index stocks increased, on average, in the post-futures versus the transition period.

Table 13 contains the overall average correlations for the five samples over the three subperiods. In every period the level of average correlation decreased from the MMI stocks to the smaller non-index stocks. In the post-futures period, however, the smaller index stocks and non-index stocks had the lowest average correlations.

The pattern across subperiods differed between the index and non-index stocks. The index stocks' average correlations tended to increase in the 


\title{
TABLE 9
}

\section{Average Correlation Coefficients for the Largest Non-MMI Stocks in the S\&P 500 Index}

\author{
Company \\ Abbott Labs \\ American Home Products \\ Amoco \\ Atlantic-Richfield \\ Boeing \\ Bristol-Myers \\ Digital Equipment \\ Dun \& Bradstreet \\ Ford Motor \\ GTE \\ Hewlett Packard \\ Lilly(Eli) \\ McDonald's \\ Pepsico \\ Pfizer \\ RJR-Nabisco \\ Royal Dutch Petroleum \\ Texaco \\ Wal-Mart \\ Westinghouse
}

\begin{tabular}{lcc} 
& Time Period & \\
\hline Pre-Futures & Transition & Post-Futures \\
& & \\
0.282 & 0.304 & 0.384 \\
0.310 & 0.310 & 0.347 \\
0.322 & 0.311 & 0.267 \\
0.323 & 0.293 & 0.240 \\
0.299 & 0.269 & 0.288 \\
0.333 & 0.349 & 0.386 \\
0.360 & 0.334 & 0.343 \\
0.193 & 0.211 & 0.384 \\
0.240 & 0.365 & 0.338 \\
0.247 & 0.329 & 0.336 \\
0.366 & 0.363 & 0.332 \\
0.313 & 0.236 & 0.344 \\
0.319 & 0.335 & 0.366 \\
0.251 & 0.293 & 0.345 \\
0.321 & 0.316 & 0.362 \\
0.292 & 0.274 & 0.321 \\
0.270 & 0.289 & 0.259 \\
0.279 & 0.286 & 0.164 \\
0.177 & 0.227 & 0.345 \\
0.337 & 0.381 & 0.376
\end{tabular}

Pre-Futures: January 2, 1980 to January $31,1982$.

Transition: $\quad$ February 1, 1982 to July 23, 1984 .

Post-Futures: July 24, 1984 to October 9, 1987.

transition period, whereas the non-index stocks' correlations declined. In the post-futures period, the MMI and smaller index stocks' average correlations dropped off, but to a level above their pre-futures level. In contrast, both non-index samples experienced a sharp increase in correlations in the postfutures period, with the larger non-index stocks' increase being the most dramatic. This additional test of covariation suggests that larger stocks experienced a significantly higher degree of comovement following the introduction of index futures trading. The average covariability of the smaller nonindex stocks increased only slightly. 


\section{TABLE 10}

\section{Average Correlation Coefficients for Smaller Stocks in the S\&P 500 Index}

Company

Ahmanson, H.F.

Amax Inc.

Armstrong World Indus.

Bethlehem Steel

Black \& Decker

Brown-Forman Distillers

Coastal Corp.

Combustion Engineering

Consolidated Freightways

Data General

E. G. \& G.

Firestone Tire \& Rubber

Great Northern Nekoosa

Great Western Financial

Harris Corp.

INTERCO, Inc.

Louisiana Land \& Expl.

Owens-Corning-Fiberglas

Polaroid

Williams Cos.

\begin{tabular}{lll} 
& Time Period & \\
\hline Pre-Futures & Transition & Post-Futures
\end{tabular}

0.166

0.134

0.178

0.205

0.188

0.107

0.183

0.201

0.101

0.215

0.224

0.161

0.216

0.205

0.216

0.151

0.200

0.170

0.190

0.232

0.247

0.194

0.221

0.138

0.247

0.188

0.138

0.196

0.198

0.218

0.156

0.170

0.135

0.160

0.163

0.170

0.220

0.212

0.177

0.126

0.201

0.186

0.201

0.151

0.240

0.218

0.216

0.243

0.186

0.176

0.178

0.210

0.142

0.226

0.195

0.206

0.190

0.184

0.111

Pre-Futures: January 2, 1980 to January $31,1982$.

Transition: February 1, 1982 to July 23, 1984.

Post-Futures: July 24, 1984 to October 9, 1987.

\section{Year-by-Year Comparisons}

To determine whether this shift to higher covariability of returns was secularly associated with the growing importance and influence of index trading, the correlations of all five samples were recalculated for each calendar year. Table 14 contains the overall results. The average correlation coefficients for the individual stocks within each sample are given in the Appendix, Tables A-1 through A-5.

For all sets, the average correlation coefficients exhibited a similar, undulating pattern over the 1980-84 period, with each sample's highest average occurring in 1982 . As in the subperiod analysis, the MMI stocks consistently 


\section{TABLE 11}

\section{Average Correlation Coefficients for the Largest Non-index Stocks}

Company

Affiliated Publications

Allegheny Power System

Ashland Oil

Carolina P\&L

Centel Corp.

Contel Corp.

First Fidelity Bancorp

FNMA

General Public Utilities

Loews Corp.

Marion Labs

Northeast Utilities

Pacific Corp.

Pennsylvania P\&L

Pinnacle West Capital

Potomac Electric Power

San Diego Gas \& Electric

Security Pacific

Union Electric

Washington Post

\begin{tabular}{ll} 
& Time Period \\
\hline Pre-Futures & Transition
\end{tabular}

0.029

0.161

0.095

0.172

0.115

0.167

0.135

0.215

0.101

0.169

0.150

0.156

0.177

0.163

0.167

0.153

0.156

0.148

0.148

0.129
Post-Futures

0.127

0.284

0.121

0.263

0.147

0.216

0.179

0.260

0.206

0.220

0.200

0.263

0.251

0.240

0.235

0.237

0.273

0.219

0.242

0.162

Pre-Futures: January 2, 1980 to January 31, 1982.

Transition: February 1, 1982 to July 23, 1984 .

Post-Futures: July 24,1984 to October 9,1987 .

had the highest covariation. The average correlations decreased from the smaller S\&P 500 stocks to the non-index stocks.

After 1984, however, the behavior of the index stocks and non-index stocks diverges. The index stocks' average correlations dropped sharply in 1985 and then increased until 1987. The smaller S\&P 500 stocks' average correlations increased 74 percent, compared to about 46 percent for the larger S\&P 500 stocks. Even at that, the 1987 levels for these two sets remained below the peak correlations of 1982 .

By contrast, the average correlations of the larger non-index stocks increased through 1986 before declining slightly in 1987 . The smaller non-index 


\section{TABLE 12}

\section{Average Correlation Coefficients for Smaller Non-index Stocks}

Company

Alco Standard

Ames Dept. Stores

Analog Devices

Arkla Inc.

Boston Edison

Central Illinois P.S.

Delmar P\&L

Harsco Corp.

Idaho Power

IPALCO Enterprises

Irving Bank

Kansas City P\&L

Kansas P\&L

Murphy Oil

Olin Corp.

Premier Industrial

Rochester Gas \& Electric

Rorer Group

Staley Continental

Telex Corp.

\begin{tabular}{lll}
\multicolumn{2}{c}{ Time Period } \\
\hline Pre-Futures & Transition & Post-Futures
\end{tabular}

0.087

0.144

0.140

0.137

0.114

0.145

0.132

0.094

0.139

0.148

0.151

0.159

0.150

0.137

0.142

0.103

0.102

0.105

0.146

0.153
0.111

0.143

0.144

0.122

0.112

0.125

0.132

0.105

0.120

0.135

0.144

0.119

0.140

0.134

0.160

0.093

0.113

0.108

0.108

0.137
0.135

0.117

0.140

0.068

0.164

0.168

0.178

0.109

0.169

0.212

0.093

0.165

0.164

0.094

0.157

0.134

0.152

0.065

0.118

0.119

Pre-Futures: January 2, 1980 to January 31,1982 .

Transition: $\quad$ February 1,1982 to July 23,1984 .

Post-Futures: July 24, 1984 to October 9, 1987.

sample's percentage increase in average correlation was also comparable to that of the index stocks, but its level of correlation was higher than in 1982.

In general, the intertemporal pattern of average correlations appears to be unstable. The degree of instability over time is tested by comparing the percentage changes in average correlation coefficients for each possible paired (year-by-year) comparison. Tables 15 through 19 contain the percentage changes in the average correlations as well as the probability values for the Box-F statistics, which are used to test the equality of the correlation matrices. To interpret the tables, consider the MMI stocks in Table 15. The upper right-hand diagonal elements represent consecutive year-over-year comparisons. For instance, the 1981 average correlation is 4.4 percent lower than 


\section{TABLE 13}

\section{Average Correlation Coefficients for the Five Stock Samples}

Stock Sample

MMI stocks

Largest non-MMI stocks in the S\&P 500

Smaller \$\&P 500 stocks

Largest non-index stocks

Smaller non-index stocks
Time Period

$\begin{array}{lcc}\text { Pre-Futures } & \text { Transition } & \text { Post-Futures } \\ & & \\ 0.331 & 0.383 & 0.364 \\ 0.292 & 0.304 & 0.326 \\ & & \\ 0.180 & 0.197 & 0.181 \\ 0.156 & 0.145 & 0.217 \\ 0.131 & 0.125 & 0.136\end{array}$

Pre-Futures: January 2, 1980 to January 31, 1982.

Transition: $\quad$ February 1, 1982 to July 23, 1984 .

Post-Futures: July 24, 1984 to October 9, 1987.

the 1980 average correlation, and one could reject the hypothesis that they are identical correlation matrices at an 8 percent level of significance.

A closer analysis of Table 15 indicates that there is very little intertemporal stability in the average correlations over the 1980-87 period, as indicated by the diagonal elements' reversal of signs. Such sign changes confirm our earlier observation that the pattern of average correlations undulates over the

\section{TABLE 14}

\section{Overall Average Correlation Coefficients for the Five Stock Samples by Calendar Years}

$\begin{array}{lcccccccc}\text { Stock Sample } & 1980 & 1981 & 1982 & 1983 & 1984 & 1985 & 1986 & 1987 \\ & & & & & & & & \\ \text { MMI stocks } & 0.340 & 0.330 & 0.458 & 0.317 & 0.360 & 0.281 & 0.368 & 0.411 \\ \begin{array}{l}\text { Largest non-MMI stocks } \\ \quad \text { in the S\&P 500 }\end{array} & 0.300 & 0.266 & 0.381 & 0.230 & 0.310 & 0.251 & 0.346 & 0.364 \\ \text { Smaller S\&P 500 stocks } & 0.206 & 0.152 & 0.244 & 0.162 & 0.201 & 0.131 & 0.177 & 0.219 \\ \text { Largest non-index stocks } & 0.172 & 0.135 & 0.172 & 0.123 & 0.151 & 0.168 & 0.257 & 0.247 \\ \text { Smaller non-index stocks } & 0.150 & 0.117 & 0.143 & 0.106 & 0.112 & 0.114 & 0.157 & 0.168\end{array}$




\section{TABLE 15}

\section{Transition Matrix of the \\ Percentage Changes in Average Correlation Coefficients of the MMI Stocks and $p$-values of the Box-F Statistics for Equality Tests of Correlation Matrices}

$\begin{array}{lccccccc} & 1980 & 1981 & 1982 & 1983 & 1984 & 1985 & 1986 \\ 1981 & -4.4 \% & & & & & & \\ & (.08) & & & & & & \\ 1982 & 34.7 \% & 40.9 \% & & & & \\ & (.00) & (.00) & & & & & \\ 1983 & -6.8 \% & -2.5 \% & -30.8 \% & & & & \\ & (.00) & (.00) & (.00) & & & & \\ 1984 & 6.2 \% & 11.1 \% & -21.2 \% & 13.9 \% & & \\ & (.00) & (.01) & (.00) & (.04) & & \\ 1985 & -17.4 \% & -13.5 \% & -38.6 \% & -11.4 \% & -22.2 \% & & \\ & (.00) & (.01) & (.00) & (.00) & (.02) & & \\ 1986 & 8.2 \% & 13.2 \% & -19.7 \% & 16.1 \% & 1.9 \% & 31.0 \% & \\ & (.00) & (.00) & (.00) & (.00) & (.00) & (.00) & \\ 1987 & 20.9 \% & 26.5 \% & -10.3 \% & 29.6 \% & 13.9 \% & 46.3 \% & 11.7 \% \\ & (.00) & (.00) & (.00) & (.00) & (.00) & (.00) & (.32)\end{array}$

Note: Each matrix element contains the percentage change in the average correlation and the associated $p$-value in parentheses for the Box-F statistic corresponding to that particular year-by-year comparison. Tests that produce significant evidence of differences at the 5 percent level are identified by boldface type. Data for 1987 ends on October 9, 1987 (prior to the market crash).

1980-85 period before increasing through 1987 . Importantly, only two yearly comparisons, $1980-81$ and 1986-87, have probability values greater than 5 percent. That is, only these two-year periods have similar correlation matrices; all other paired comparisons indicate that the correlation matrices are statistically different. Moreover, the correlation matrices for the 1986 and 1987 periods, when program trading activities were the greatest, are statistically different from those of earlier years, but are not statistically different from each other. Therefore, except for 1982, these two years' correlations tend to be both higher and different from those of prior years.

For the larger non-MMI stocks (Table 16), an even more interesting relation occurs. A similar sign-reversal tendency in average correlations occurs over consecutive yearly comparisons. Note, however, that none of the 


\section{TABLE 16}

\section{Transition Matrix of the Percentage Changes in Average Correlation Coefficients of the Largest Non-MMI Stocks in the S\&P 500 Index and $p$-values of the Box-F Statistics for Equality Tests of Correlation Matrices} $\begin{array}{lllllll}1980 & 1981 & 1982 & 1983 & 1984 & 1985 & 1986\end{array}$

$\begin{array}{lrrrrrrr}1981 & -11.3 \% & & & & & \\ & (.41) & & & & & \\ 1982 & 27.0 \% & 43.2 \% & & & & \\ & (.73) & (.75) & & & & \\ 1983 & -23.3 \% & -13.5 \% & -39.6 \% & & & & \\ & (.45) & (.34) & (.22) & & & & \\ 1984 & 3.3 \% & 16.5 \% & -18.6 \% & 34.8 \% & & & \\ & . .34) & (.59) & (.60) & (.27) & & & \\ 1985 & -16.3 \% & -5.6 \% & -34.1 \% & 34.8 \% & -19.0 \% & & \\ & (.04) & (.46) & (.13) & (.01) & .96) & & \\ 1986 & 15.3 \% & 30.1 \% & -9.2 \% & 50.4 \% & 11.6 \% & 37.8 \% & \\ & (.00) & (.00) & (.03) & (.00) & (.01) & . .06) & \\ 1987 & 21.3 \% & 36.8 \% & -4.5 \% & 58.3 \% & 17.4 \% & 45.0 \% & 5.2 \% \\ & (.01) & (.00) & (.03) & (.00) & (.00) & (.01) & (.06)\end{array}$

Note: Each matrix element contains the percentage change in the average correlation and the associated $p$-value in parentheses for the Box-F statistic corresponding to that particular year-by-year comparison. Tests that produce significant evidence of differences at the 5 percent level are identified by boldface type. Data for 1987 ends on October 9, 1987 (prior to the market crash).

paired comparisons indicates that the correlation structure is different. In fact, except for the 1983-85 comparison, the 1986 and 1987 correlations of these stocks are statistically different and higher than those of prior years, but not as compared to each other. Whereas 1985 is different from 1980 and 1983, its correlations are lower, on average, and occur early in the post-futures period.

The information in Table 17 indicates that the behavior of smaller nonindex stocks closely mimicked the behavior of MMI stocks, leading to the conclusion that these stocks experienced a stronger interrelation in 1986-87 than in prior years. Average correlations for the larger non-MMI stocks, however, seem to indicate significant differences in their interrelation over time, primarily in 1986 and 1987 . Because the Box-F equality test takes more 


\section{TABLE 17}

\section{Transition Matrix of the Percentage Changes in Average Correlation Coefficients of the Smaller S\&P 500 Index Stocks and $p$-values of the Box-F Statistics for Equality Tests of Correlation Matrices}

$\begin{array}{lccccccc} & 1980 & 1981 & 1982 & 1983 & 1984 & 1985 & 1986 \\ 1981 & -23.8 \% & & & & & & \\ & (.72) & & & & & & \\ 1982 & 18.4 \% & 55.4 \% & & & & & \\ & (.00) & (.00) & & & & & \\ 1983 & -21.4 \% & 3.2 \% & -33.6 \% & & & & \\ & (.00) & (.00) & (.01) & & & & \\ 1984 & -2.4 \% & 28.0 \% & -17.6 \% & 24.1 \% & & & \\ & (.00) & (.00) & (.00) & (.00) & & & \\ 1985 & -38.8 \% & -19.7 \% & -48.4 \% & -22.2 \% & -37.3 \% & & \\ & (.00) & (.00) & (.00) & (.00) & (.04) & & \\ 1986 & -14.1 \% & 12.7 \% & -27.4 \% & 9.3 \% & -11.9 \% & 40.5 \% & \\ & (.00) & (.00) & (.00) & (.00) & (.00) & (.00) & \\ 1987 & 6.3 \% & 39.4 \% & -10.2 \% & 35.2 \% & 9.0 \% & 73.8 \% & 23.7 \% \\ & (.00) & (.00) & (.00) & (.00) & (.00) & (.00) & (.27)\end{array}$

Note: Each matrix element contains the percentage change in the average correlation and the associated $p$-value in parentheses for the Box-F statistic corresponding to that particular year-by-year comparison. Tests that produce significant evidence of differences at the 5 percent level are identified by boldface type. Data for 1987 ends on October 9, 1987 (prior to the market crash).

information into account (namely, the entire structure of individual correlations), it utilizes information concerning the individual paired correlations. For instance, the 43.2 percent increase in average correlations from 1981 to 1982 (Table 16) appears at first to be quite sizable. The probability of 0.75 , however, indicates that the two correlation sets are actually indistinguishable. Consequently, the large apparent increase is not statistically significant.

Tables 18 and 19 indicate once again that the behavior of the large non-index stocks is strikingly similar to that of the MMI stocks and smaller S\&P 500 stocks. The exceptions occur in 1985 and 1986, when the correlations are statistically indistinguishable from each other. 


\section{TABLE 18}

\section{Transition Matrix of the Percentage Changes in Average Correlation Coefficients of the Largest Non-index Stocks and $p$-values of the Box-F Statistics for Equality Tests of Correlation Matrices}

$\begin{array}{lllllll}1980 & 1981 & 1982 & 1983 & 1984 & 1985 & 1986\end{array}$

$\begin{array}{lccccccc}1981 & -21.5 \% & & & & & \\ & (.13) & & & & & \\ 1982 & 0.0 \% & 27.4 \% & & & & \\ & (.01) & (.00) & & & & \\ 1983 & -28.5 \% & -8.9 \% & -28.5 \% & & & \\ & (.00) & (.00) & (.04) & & & \\ 1984 & -12.2 \% & 11.9 \% & -12.2 \% & 22.8 \% & & & \\ & (.00) & (.00) & (.00) & (.00) & & & \\ 1985 & -2.3 \% & -24.4 \% & -2.3 \% & 36.6 \% & 11.3 \% & \\ & (.00) & (.01) & (.00) & (.04) & (.03) & & \\ 1986 & 49.4 \% & 90.4 \% & 49.4 \% & 108.9 \% & 70.2 \% & 53.0 \% & \\ & (.00) & (.00) & (.00) & (.00) & (.01) & .26) & \\ 1987 & 43.6 \% & 83.0 \% & 43.6 \% & 100.8 \% & 63.6 \% & 47.0 \% & -3.9 \% \\ & (.01) & (.00) & (.00) & (.01) & (.02) & (.00) & (.09)\end{array}$

Note: Each matrix element contains the percentage change in the average correlation and the associated $p$-value in parentheses for the Box-F statistic corresponding to that particular year-by-year comparison. Tests that produce significant evidence of differences at the 5 percent level are identified by boldface type. Data for 1987 ends on October 9, 1987 (prior to the market crash).

The smaller non-index stocks provide the most interesting result. Although their covariability appears to strengthen over the 1983-87 period (see the bottom of Table 14), this was not, in fact, the case. The probability values in Table 19 indicate that only the 1985 period was consistently different from prior years. In other words, smaller non-index stocks' correlations were surprisingly quite stable over the entire period.

Our yearly analysis, therefore, finds that almost all stocks tended to possess higher covariation in the post-futures period. Their comovement apparently increased consistently through 1987 . The only exception is non- 


\section{TABLE 19}

\section{Transition Matrix of the Percentage Changes in Average Correlation Coefficients of the Smaller Non-index Stocks and $p$-values of the Box-F Statistics for Equality Tests of Correlation Matrices}

$\begin{array}{lrrrrrrr} & 1980 & 1981 & 1982 & 1983 & 1984 & 1985 & 1986 \\ 1981 & -22.0 \% & & & & & & \\ & (.56) & & & & & & \\ 1982 & -4.7 \% & 22.2 \% & & & & & \\ & (.72) & (.01) & & & & & \\ 1983 & -29.3 \% & -9.4 \% & -25.9 \% & & & & \\ & (.28) & (.19) & (.57) & & & & \\ 1984 & -25.3 \% & -4.3 \% & -21.7 \% & 5.7 \% & & & \\ & (.22) & (.01) & (.19) & (.21) & & & \\ 1985 & -24.0 \% & -2.6 \% & -20.3 \% & 7.5 \% & 1.8 \% & & \\ & (.02) & (.02) & (.01) & (.00) & (.09) & & \\ 1986 & 4.7 \% & 34.2 \% & 9.8 \% & 48.1 \% & 40.2 \% & 37.8 \% & \\ & (.84) & (.11) & (.52) & (.20) & (.39) & (.74) & \\ 1987 & 12.0 \% & 43.6 \% & 17.5 \% & 58.5 \% & 50.0 \% & 47.4 \% & 7.0 \% \\ & (.93) & (.24) & (.38) & (.42) & (.30) & (.20) & (.91)\end{array}$

Note: Each matrix element contains the percentage change in the average correlation and the associated $p$-value in parentheses for the Box-F statistic corresponding to that particular year-by-year comparison. Tests that produce significant evidence of differences at the 5 percent level are identified by boldface type. Data for 1987 ends on October 9, 1987 (prior to the market crash).

index stocks, whose average correlations appeared highest in 1987 . The index stocks' correlations were higher only in 1982 . Moreover, the 1986 and 1987 average correlations were statistically different from those of prior years but were not different from each other. This, however, was not the case for the smaller non-index stocks. Rather, these stocks' interrelation was found to be relatively unchanged, except in 1985 .

This evidence corroborates the hypothesis that index stocks experienced a greater degree of covariability following the introduction of index futures and options. Moreover, their high covariability in 1987 contributed disproportionately to the elevated level of comovement in the post-futures period. Two 
possible explanations may be offered. First, because of their size, non-index stocks tend to be included in core portfolios that are subject to program trading activities. Second, interest-rate-sensitive stocks are overrepresented in the sample: Given that the stock market's strength from mid-1984 to 1986 was largely interest-rate driven, their higher degree of comovement may simply reflect this period's large drop in interest rates. ${ }^{2}$

\section{Comparisons of High- and Low-Intensity Program Trading Days}

The unusual shift in the index stocks' average correlations requires further analysis. Returns in 1987 were dichotomized into high- and low-intensity program trading days to permit closer examination of the influence of program trading. An index of program trading intensity and daily measurements of this index are adopted from Grossman (1988). This index is defined as "the total number of program orders (purchases plus sales, measured in shares) as a percentage of total NYSE orders.",4 As part of the Brady Commission (the Presidential Task Force on Market Mechanisms), Grossman and the NYSE estimated the index, or percentage, values on a daily basis from January 2

\footnotetext{
${ }^{2}$ Earlier, we noted that this sample comprises primarily utilities and financials.

${ }^{3} \mathrm{~A}$ second definition of program trading intensity used by Grossman is the number of program orders (in shares) as a percentage of designated order turnaround (DOT) orders (in shares) for the day. We chose the first definition for this study because some program trades do not use the DOT system, and, hence, the second definition is not as encompassing a measure of program trading activity, although we suspect that the two index definitions are highly related. In fact, even these two measures are somewhat deficient in that program trades also occur off-exchange in the over-the-counter market or overseas (such as on the London Stock Exchange) and, thus, do not appear in the NYSE's compiled statistics on program trading volume. For instance, more than 400 institutions trade through two off-exchange electronic systems the Jefferies \& Co. Posit system, which specializes in third-market stock trading, and Crossing Network, run by the Instinet subsidiary of Reuters Holdings PLC. Program trading done through these two systems, however, may not have much time impact on systematic risk and individual stocks' covariability, because the Posit system usually executes its orders during the slow midday period, whereas the Crossing Network operates after trading hours on the NYSE.

${ }^{4}$ Recently in Weiss (1989), this definition was called into question because it inflates by 100 percent the actual rate of program trading. To be consistent with formulas for other forms of trading, purchases and sale orders should be divided by twice the total NYSE orders. This has no effect, however, on how we identify high-versus low-intensity program trading days.
} 
through October 30, 1987. For our study, we define a high-intensity program trading day as one in which program trading accounted for 4 percent or more of total volume. Of the 211 trading days in the January-October period, 87 were high-intensity days; the remaining 124 days were low-intensity days. The median high-intensity index value was 5.18 percent, with the high-intensity index ranging from 4.07 percent (June 1) to 18.94 percent (June 19). For the low-intensity days, the median index value was 2.75 percent. Its smallest value was 0.86 percent (March 10 ).

Table 20 summarizes average correlations by program-trading-intensity day and for all trading days. The individual stocks' average correlations are given in the Appendix as Tables A-6 to A-10. The first two columns of Table 20 indicate that stocks' average correlations are generally greater on highintensity trading days than on low-intensity trading days. The smaller nonindex stocks' correlations are an exception; they were higher on low-intensity trading days. Regardless of type of day, the MMI stocks' average correlations are the highest (the first three columns). All average correlations decrease as one reads down the first three columns. The larger non-index stocks' correlations are consistently higher than those of the smaller S\&P 500 stocks. Columns 4 and 5 indicate that the relative difference between the correlations on high- and low-intensity days decreases from the MMI to the smaller

\section{TABLE 20}

\section{Summary of Average Correlations for the Five Stock Samples \\ Over High- and Low-Intensity Program Trading Days during 1987}

\begin{tabular}{|c|c|c|c|c|c|}
\hline Stock Sample & $\begin{array}{c}\text { (1) } \\
\text { High- } \\
\text { Intensity }\end{array}$ & $\begin{array}{c}\text { (2) } \\
\text { Low- } \\
\text { Intensity }\end{array}$ & $\begin{array}{l}\text { (3) } \\
\text { All } \\
\text { Trading } \\
\text { Days }\end{array}$ & $\begin{array}{c}(4) \\
\text { Relative } \\
\text { Differences } \\
(1) \div(2)\end{array}$ & $\begin{array}{l}\text { Number } \\
\text { Larger }\end{array}$ \\
\hline MMI stocks & 0.569 & 0.343 & 0.411 & 1.659 & 20 \\
\hline $\begin{array}{l}\text { Largest non-MMI stocks } \\
\text { in the S\&P } 500 \\
\text { Smaller index stocks }\end{array}$ & 0.481 & 0.322 & 0.364 & 1.494 & 19 \\
\hline $\begin{array}{l}\text { Smaller index stocks } \\
\text { in the S\&P } 500 \\
\text { Largest non-index stocks } \\
\text { Smaller non-index stocks }\end{array}$ & $\begin{array}{l}0.275 \\
0.289 \\
0.148\end{array}$ & $\begin{array}{l}0.193 \\
0.234 \\
0.177\end{array}$ & $\begin{array}{l}0.219 \\
0.247 \\
0.169\end{array}$ & $\begin{array}{l}1.425 \\
1.235 \\
0.836\end{array}$ & $\begin{array}{r}17 \\
17 \\
7\end{array}$ \\
\hline
\end{tabular}


non-index stocks. The number of stocks with higher correlations on high-intensity days decreases as well.

Finally, except for those of the smaller non-index stocks, the probability values indicate that the covariability among the stocks in each sample is different when the trading days are divided by degree of program trading intensity. These results provide the strongest evidence that program trading increased index stocks' covariability. In general, larger non-index stocks also experienced a higher degree of comovement on high-intensity days. The relative difference between their correlations on high- and low-intensity days is less than that for the index stocks. The smaller non-index stocks behaved oppositely from the other stocks. Their average correlations were lower (higher) on high- (low-) intensity program trading days. 


\section{Implications For Investment Analysis}

Because investment strategies depend on securities' return correlations, the impact of derivative asset trading on stock behavior has a number of implications for investment analysis. At least five segments of investment analysis may be affected.

\section{Security analysis}

A stock with relatively high nonsystematic risk relative to its systematic risk will generate returns that deviate more from movements in the overall market because it responds more to firm-specific news that does not affect other stocks. Such stocks are inherently difficult to analyze and require close monitoring. Accordingly, they provide analysts with opportunities to make a valuable contribution by applying their special expertise and knowledge.

Conversely, stocks with high systematic risk are more sensitive to macroeconomic events. Stocks with high market sensitivity afford fewer surprises. There is less payoff to devoting research resources to them. Similarly, stocks that are actively traded as part of basket trading may exhibit such a high degree of correlation with the market and among themselves that, once again, the expected payoff to analyzing and monitoring them would be greatly diminished.

\section{Beta forecasts}

Analysts are also concerned with developing forecasts of a security's risk as measured by beta. Usually, beta estimates are made using the statistical technique of regression analysis. This technique is very sensitive to the time interval and measurement period selected for estimation. If the hypothesized 
impact of program trading is present, then the proper period over which to estimate betas and the time interval for observing data are now more important than ever.

Similarly, various adjustment techniques used to reduce measurement errors, bias, or inefficiencies in beta predictions may also be affected. For example, Bayesian adjustments are used to reduce bias by combining a security's estimated beta with the average historical beta for its industry. ${ }^{1}$ If basket trading affects systematic risk, even these adjustments must be scrutinized and used with caution.

Conversely, one might argue that if program trading has significantly increased index stocks' systematic risk, beta estimation may improve, provided that the historical period and interval are carefully chosen. That is, the total error in the estimate may be caused by largely random events. These events should be dissipated under the hypothesized increase (decrease) in systematic (nonsystematic) price behavior. Nevertheless, the problem of generating an accurate forecast of the level of beta still remains. This problem is especially important because it takes more securities to control beta measurement errors than to control unsystematic risk in terms of their impact on portfolios.

\section{Portfolio analysis and selection}

Analysts also use various statistical techniques such as discriminant analysis and factor models to forecast the correlation-covariance structure among securities to simplify the portfolio analysis and selection problem. ${ }^{2}$ These techniques require an assumption about the underlying stability of correlations among stocks. If the correlations change dramatically, the models become suspect unless adjusted for the changes.

Similarly, the success of homogeneous grouping and sector or industry rotation strategies also depends on the underlying correlation-covariance structure across sectors or industries as well as within them. ${ }^{3}$ For instance, a homogeneous group strategy, wherein larger, institutional-quality stocks are

\footnotetext{
${ }^{1}$ For example, see Blume (1975), Klemkosky and Martin (1975), and Vasicek (1973).

${ }^{2}$ For example, see Elton and Gruber (1973), Elton, Gruber, and Padberg (1976), and Elton, Gruber, and Urich (1978).

${ }^{3}$ For example, see Farrell (1974) and Sorenson and Burke (1986).
} 
categorized as growth, cyclical, stable, or energy-related, relies on an expected pattern of correlation among the sectors. Homogeneously grouped stocks are expected to be positively and highly correlated within their group and less highly correlated with other groups. Moreover, the groups themselves are not expected to be highly correlated. The success of sector rotation depends on this lack of correlation. If the average correlations increase, stock returns tend to homogenize, and this may be reflected in stocks' systematic risk. Thus, the introduction of program trading may have disrupted the tendency of these groups to move out of phase with one another, and index-stock returns may no longer move in concert with the same group or industry classifications.

\section{Equity diversification}

Portfolio optimization controls portfolio risk and expected return by efficient diversification. The objective is to minimize risk, given expected returns, or to maximize expected returns, given risk. Total portfolio risk is reduced by combining securities whose nonsystematic risks are not highly correlated. The potential for effective diversification depends on the correlations among securities' returns. If the correlations among index stocks have increased, their potential diversification benefits have been reduced, perhaps significantly. This result has at least two implications. First, the traditional strategy of diversifying across industries to reduce systematic risk needs to be amended for index stocks. Second, the universe of stocks considered by institutional investors needs to be widened, because the traditional set may no longer be sufficient to eliminate nonsystematic risk with a reasonable number of securities.

\section{Asset allocation}

Most strategic asset allocation models explicitly or implicitly rely on estimates of the variances and correlations of different asset classes. ${ }^{4}$ These estimates are usually computed by using historical data, although a risk premium approach may sometimes be used. Those models that use scenario or simulation analysis often assume that risks and correlations remain constant over the forecast period, which may extend as far as three to five years into the future. If program trading has altered the systematic risk of institu-

\footnotetext{
${ }^{4}$ For example, see Fong (1980), Fouse (1987), and Sharpe (1987).
} 
tionally traded stocks, historically based values will no longer reflect the new market dynamics.

Add to these implications such recently developed market basket products as the NYSE's Exchange Stock Portfolios and the CBOE's Market Basket Security, ${ }^{5}$ and it is possible that the impact of program trading on systematic price behavior may be growing. ${ }^{6}$

${ }^{5}$ See Rubinstein (1989) for a discussion of alternative market basket securities.

${ }^{6}$ Program trading has emigrated to stock markets in London and Tokyo. London has instituted two derivative instruments-the Financial Times-Stock Exchange futures contract, traded on the London International Financial Futures Exchange, and the FT-SE index option contract, traded on the London Stock Exchange's Traded Options Market. Although small compared to the U.S. derivative asset markets, both contracts have grown since the $1987 \mathrm{global}$ market crash. Program trading has taken off in Japan since the 1988 introduction of stock index futures trading on the Tokyo and Osaka stock exchanges. Not surprisingly, program trading has been faulted for recent volatility in the Nikkei 225 stock index. 


\section{Conclusions}

This research has attempted to determine whether the advent of index futures and options trading in 1982 may have had another possible, but more subtle, impact on cash market prices. The study's primary hypothesis is that the systematic relationship of the Major Market Index (MMI), the S\&P 500 Index, and five samples of 20 stocks each increased in the post-futures period. We further hypothesized that this phenomenon results from investment strategies that involve the simultaneous buying and selling of baskets of stocks. We conjectured that such synchronous trading may lead to a higher degree of comovement among index stocks' prices.

The empirical evidence supports a sizable and statistically significant increase in percentage systematic risk for the MMI and larger index stocks, but not for smaller index stocks. Larger (but not smaller) non-index stocks also experienced an increase in percentage systematic risk. This suggests that synchronized basket trading may primarily affect larger stocks contained in such market indexes as the MMI or the S\&P 500. A possible explanation for this result is that such stocks are usually integral components of program trades, whereas smaller stocks are not.

More important, we found that, on average, there is a significant increase in covariability among larger index and non-index stocks' returns in the post-futures period compared to their historical (pre-futures) relationship. The increase in correlations was not evident in smaller index or non-index stocks. The yearly pattern in stocks' average correlations tended to mimic the overall trend in index trading; for example, they escalated rapidly from 1985 through 1987. The larger non-index stocks were an exception. 
Because it reached a high-water mark in 1987, we examined program trading in this year more closely by categorizing the trading days as high or low program trading intensity. An even more dramatic increase in correlations was found for high-intensity program trading days. Moreover, a clear, positive relation existed between firm size and the relative difference between correlations on high- and low-intensity days.

On the one hand, these results are consistent with the notion that the introduction of index futures and options trading increased the degree of comovement among index stocks. On the other hand, size may account for the higher covariability among larger non-index stocks, because their size alone makes them candidates for core portfolios that are subject to program trading. Another reason may be that most of these stocks are interest-rate sensitive. Their return performance may have been uniformly affected by the large decrease in interest rates during the post-futures periods.

Our results lend credibility to the disturbing conclusion that a significant portion of index stocks' returns may now be determined more by momentum (short-term) rather than value-based (long-term) trading strategies. In this scenario, returns bear little relation to fundamental firm valuation factors and, in the extreme, become homogenized as stocks are traded more like commodities. In other words, program traders "don't even care what the names of the stocks are-[stocks] are just numbers" to them. ${ }^{1}$ Although this is not necessarily our opinion, our results suggest that there is merit to this controversial viewpoint.

All studies are subject to the same cautionary note: More remains to be done. This is true of our research as well. Five provisos are needed to place our study in proper perspective. First, our results and conclusions are preliminary until additional market data become available, especially with the resurgence in program trading since 1987. Although the analysis of more data is not always better, it is likely to be so in a study of this sort.

Second, the approach adopted in this research measures the degree of association and not causality between program trading and price movements. A more refined methodology might measure changes in index and non-index stocks' responsiveness to macroeconomic events, such as unexpected infla-

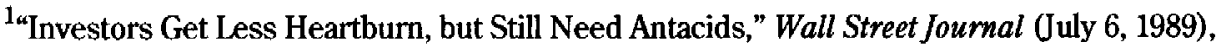
p. C1.
} 
tion and the spread between long- and short-term interest rates. Another tack would be to measure changes in the relation of each stock's fundamental characteristics, such as earnings growth and debt usage, to its systematic risk before and after the introduction of index futures and options. If program trading affects systematic behavior, larger index stocks' responsiveness to macroeconomic factors will increase, and their responsiveness to fundamental factors will decrease.

Third, the observed increase in covariation may result simply from greater liquidity or trading volume in the post-futures period. In turn, this may mitigate the effect of such market frictions as nonsynchronous trading and other price-adjustment delay factors that may bias downward the early years' correlations.

Fourth, many firms underwent major restructuring, leveraging, productline expansion, and external acquisition programs during the 1980-87 study period. For instance, the breakup of AT\&T (1984), USX's acquisition of Marathon Oil (1982) and Texas Oil \& Gas (1986), and GM's purchase of EDS (1984) and Hughes Aircraft (1985) have had profound effects on these firms' operating and financial characteristics. Are these the same companies today as in the pre-futures period? Such changes require us to be cautious in interpreting comparisons between the pre- and post-futures periods.

Fifth, a fundamental change also may have occurred in the market indexes themselves. In recent years, Standard \& Poor's has tended to substitute low-yield, high price-to-book growth stocks for low-growth, cyclical stocks in their broad market index. These substitutions may have changed the character of the index and altered historic norms. 


\section{Appendix}

Correlation Coefficients for Individual Stocks 


\section{TABLE A-1}

\section{Transition Matrix of Average Correlation Coefficients of the MMI Stocks by Calendar Years}

$\begin{array}{lllllllll}\text { Company } & 1980 & 1981 & 1982 & 1983 & 1984 & 1985 & 1986 & 1987 \\ & & & & & & & & \\ \text { American Express } & 0.358 & 0.327 & 0.505 & 0.289 & 0.393 & 0.335 & 0.403 & 0.345 \\ \text { AT\&T* }^{\star} & 0.264 & 0.267 & 0.425 & 0.264 & 0.291 & 0.322 & 0.398 & 0.406 \\ \text { Chevron } & 0.334 & 0.394 & 0.400 & 0.323 & 0.283 & 0.196 & 0.278 & 0.404 \\ \text { Coca-Cola } & 0.283 & 0.283 & 0.430 & 0.293 & 0.411 & 0.228 & 0.422 & 0.439 \\ \text { Dow Chemical } & 0.376 & 0.375 & 0.447 & 0.337 & 0.380 & 0.320 & 0.390 & 0.420 \\ \text { DuPont } & 0.395 & 0.334 & 0.498 & 0.348 & 0.413 & 0.238 & 0.418 & 0.484 \\ \text { Eastman Kodak } & 0.374 & 0.417 & 0.523 & 0.231 & 0.332 & 0.315 & 0.318 & 0.411 \\ \text { Exxon } & 0.348 & 0.330 & 0.432 & 0.355 & 0.264 & 0.259 & 0.400 & 0.443 \\ \text { General Electric } & 0.406 & 0.406 & 0.548 & 0.375 & 0.465 & 0.397 & 0.470 & 0.513 \\ \text { General Motors } & 0.331 & 0.334 & 0.502 & 0.360 & 0.437 & 0.338 & 0.365 & 0.376 \\ \text { IBM } & 0.403 & 0.398 & 0.548 & 0.429 & 0.491 & 0.385 & 0.345 & 0.383 \\ \text { International Paper } & 0.325 & 0.310 & 0.446 & 0.283 & 0.353 & 0.224 & 0.357 & 0.418 \\ \text { Johnson \& Johnson } & 0.314 & 0.358 & 0.440 & 0.270 & 0.332 & 0.262 & 0.363 & 0.495 \\ \text { Merck \& Co. } & 0.352 & 0.235 & 0.414 & 0.277 & 0.317 & 0.312 & 0.390 & 0.398 \\ \text { Minn. Mining \& Mfg. } & 0.375 & 0.346 & 0.531 & 0.351 & 0.400 & 0.324 & 0.451 & 0.459 \\ \text { Mobil } & 0.276 & 0.283 & 0.398 & 0.342 & 0.262 & 0.178 & 0.295 & 0.355 \\ \text { Philip Morris } & 0.348 & 0.353 & 0.457 & 0.267 & 0.370 & 0.217 & 0.357 & 0.443 \\ \text { Proctor \& Gamble } & 0.328 & 0.266 & 0.454 & 0.264 & 0.335 & 0.222 & 0.403 & 0.433 \\ \text { Sears } & 0.328 & 0.327 & 0.518 & 0.386 & 0.375 & 0.327 & 0.427 & 0.402 \\ \text { USX } & 0.273 & 0.253 & 0.242 & 0.302 & 0.301 & 0.224 & 0.116 & 0.194\end{array}$

* AT\&'T, which resulted from a court-ordered breakup of the Bell System, received about 23 percent of the former company's assets. Therefore, post-divestiture data after 1983 are not comparable to the predivestiture data. 
TABLE A-2

\section{Transition Matrix of Average Correlation Coefficients for the Largest Non-MMI Stocks in the S\&P 500 Index by Calendar Years}

$\begin{array}{lcccccccc}\text { Company } & 1980 & 1981 & 1982 & 1983 & 1984 & 1985 & 1986 & 1987 \\ & & & & & & & & \\ \text { Abbott Labs } & 0.302 & 0.250 & 0.369 & 0.236 & 0.320 & 0.324 & 0.389 & 0.440 \\ \text { American Home Prod. } & 0.323 & 0.292 & 0.381 & 0.222 & 0.334 & 0.259 & 0.392 & 0.369 \\ \text { Amoco } & 0.337 & 0.291 & 0.390 & 0.255 & 0.230 & 0.160 & 0.300 & 0.353 \\ \text { Atlantic-Richfield } & 0.326 & 0.300 & 0.401 & 0.234 & 0.193 & 0.111 & 0.232 & 0.364 \\ \text { Boeing } & 0.300 & 0.276 & 0.342 & 0.177 & 0.332 & 0.310 & 0.331 & 0.173 \\ \text { Bristol-Myers } & 0.335 & 0.316 & 0.441 & 0.229 & 0.385 & 0.325 & 0.379 & 0.443 \\ \text { Digital Equipment } & 0.400 & 0.302 & 0.467 & 0.225 & 0.345 & 0.284 & 0.342 & 0.372 \\ \text { Dun \& Bradstreet } & 0.209 & 0.156 & 0.257 & 0.186 & 0.261 & 0.282 & 0.415 & 0.456 \\ \text { Ford Motor } & 0.250 & 0.232 & 0.396 & 0.308 & 0.387 & 0.284 & 0.339 & 0.349 \\ \text { GTE } & 0.226 & 0.252 & 0.383 & 0.264 & 0.351 & 0.257 & 0.342 & 0.367 \\ \text { Hewlett Packard } & 0.363 & 0.345 & 0.475 & 0.253 & 0.362 & 0.262 & 0.337 & 0.356 \\ \text { Lilly (Eli) } & 0.333 & 0.266 & 0.320 & 0.128 & 0.260 & 0.264 & 0.362 & 0.410 \\ \text { McDonald's } & 0.327 & 0.288 & 0.418 & 0.256 & 0.339 & 0.303 & 0.370 & 0.420 \\ \text { PepsiCo } & 0.247 & 0.246 & 0.375 & 0.194 & 0.307 & 0.264 & 0.361 & 0.394 \\ \text { Pfizer } & 0.357 & 0.252 & 0.381 & 0.263 & 0.323 & 0.324 & 0.382 & 0.394 \\ \text { RJR-Nabisco } & 0.313 & 0.248 & 0.355 & 0.212 & 0.258 & 0.241 & 0.348 & 0.380 \\ \text { Royal Dutch Petroleum } & 0.253 & 0.265 & 0.341 & 0.252 & 0.288 & 0.237 & 0.290 & 0.241 \\ \text { Texaco } & 0.294 & 0.263 & 0.371 & 0.237 & 0.235 & 0.076 & 0.231 & 0.134 \\ \text { Wal-Mart } & 0.166 & 0.162 & 0.280 & 0.176 & 0.317 & 0.175 & 0.367 & 0.422 \\ \text { Westinghouse } & 0.332 & 0.325 & 0.468 & 0.290 & 0.378 & 0.276 & 0.401 & 0.448\end{array}$




\section{TABLE A-3}

\section{Transition Matrix of Average Correlation Coefficients for the Smaller S\&P 500 Index Stocks by Calendar Years}

$\begin{array}{lllllllll}\text { Company } & 1980 & 1981 & 1982 & 1983 & 1984 & 1985 & 1986 & 1987 \\ & & & & & & & & \\ \text { Ahmanson, H.F } & 0.200 & 0.124 & 0.258 & 0.170 & 0.289 & 0.137 & 0.230 & 0.256 \\ \text { Amax } & 0.183 & 0.118 & 0.319 & 0.193 & 0.170 & 0.122 & 0.143 & 0.116 \\ \text { Armstrong World Indus. } & 0.189 & 0.160 & 0.220 & 0.164 & 0.225 & 0.180 & 0.231 & 0.225 \\ \text { Bethlehem Steel } & 0.206 & 0.191 & 0.285 & 0.215 & 0.290 & 0.156 & 0.127 & 0.137 \\ \text { Black \& Decker } & 0.246 & 0.140 & 0.202 & 0.130 & 0.262 & 0.121 & 0.141 & 0.219 \\ \text { Brown-Forman Distillers } & 0.138 & 0.072 & 0.200 & 0.088 & 0.083 & 0.060 & 0.130 & 0.220 \\ \text { Coastal Corp. } & 0.258 & 0.110 & 0.285 & 0.136 & 0.059 & 0.068 & 0.185 & 0.241 \\ \text { Combustion Engineering } & 0.227 & 0.166 & 0.238 & 0.159 & 0.171 & 0.121 & 0.172 & 0.227 \\ \text { Consol. Freightways } & 0.120 & 0.075 & 0.210 & 0.137 & 0.174 & 0.166 & 0.232 & 0.232 \\ \text { Data General } & 0.254 & 0.183 & 0.284 & 0.147 & 0.249 & 0.161 & 0.156 & 0.173 \\ \text { E. G. \& G. } & 0.239 & 0.200 & 0.240 & 0.207 & 0.226 & 0.126 & 0.189 & 0.253 \\ \text { Firestone Tire/Rubber } & 0.148 & 0.171 & 0.225 & 0.171 & 0.186 & 0.132 & 0.181 & 0.256 \\ \text { Great Northern Nekoosa } & 0.239 & 0.194 & 0.204 & 0.100 & 0.198 & 0.121 & 0.213 & 0.281 \\ \text { Great Western Financial } & 0.207 & 0.193 & 0.287 & 0.190 & 0.284 & 0.166 & 0.239 & 0.274 \\ \text { Harris Corp. } & 0.256 & 0.158 & 0.245 & 0.214 & 0.176 & 0.158 & 0.184 & 0.230 \\ \text { INTERCO, Inc. } & 0.179 & 0.120 & 0.213 & 0.154 & 0.153 & 0.105 & 0.208 & 0.204 \\ \text { Louisiana Land \& Expl. } & 0.221 & 0.191 & 0.240 & 0.166 & 0.182 & 0.098 & 0.091 & 0.271 \\ \text { Owens-Corning-Fiberglas } & 0.183 & 0.157 & 0.251 & 0.198 & 0.247 & 0.216 & 0.170 & 0.244 \\ \text { Polaroid } & 0.201 & 0.168 & 0.247 & 0.156 & 0.227 & 0.134 & 0.218 & 0.190 \\ \text { Williams Cos. } & 0.219 & 0.150 & 0.222 & 0.140 & 0.175 & 0.070 & 0.102 & 0.124\end{array}$


TABLE A-4

\section{Transition Matrix of Average Correlation Coefficients for the Largest Non-index Stocks by Calendar Years}

$\begin{array}{lllllllll}\text { Company } & 1980 & 1981 & 1982 & 1983 & 1984 & 1985 & 1986 & 1987 \\ & & & & & & & & \\ \text { Affiliated Publications } & 0.102 & 0.046 & 0.024 & 0.046 & 0.053 & 0.057 & 0.168 & 0.170 \\ \text { Allegheny Power System } & 0.232 & 0.168 & 0.184 & 0.154 & 0.156 & 0.233 & 0.316 & 0.331 \\ \text { Ashland Oil } & 0.176 & 0.059 & 0.121 & 0.107 & 0.082 & 0.110 & 0.113 & 0.144 \\ \text { Carolina P\&L } & 0.220 & 0.184 & 0.237 & 0.106 & 0.154 & 0.203 & 0.323 & 0.316 \\ \text { Centel Corp. } & 0.203 & 0.153 & 0.152 & 0.102 & 0.126 & 0.089 & 0.128 & 0.215 \\ \text { Contel Corp. } & 0.239 & 0.141 & 0.221 & 0.131 & 0.194 & 0.174 & 0.238 & 0.218 \\ \text { First Fidelity Bancorp } & 0.109 & 0.121 & 0.156 & 0.106 & 0.150 & 0.143 & 0.243 & 0.149 \\ \text { FNMA } & 0.202 & 0.198 & 0.264 & 0.176 & 0.216 & 0.218 & 0.309 & 0.280 \\ \text { General Public Utilities } & 0.067 & 0.077 & 0.137 & 0.074 & 0.091 & 0.143 & 0.286 & 0.265 \\ \text { Loews Corp. } & 0.216 & 0.161 & 0.198 & 0.133 & 0.170 & 0.173 & 0.249 & 0.255 \\ \text { Marion Labs } & 0.085 & 0.092 & 0.125 & 0.171 & 0.160 & 0.121 & 0.222 & 0.266 \\ \text { Northeast Utilities } & 0.161 & 0.138 & 0.179 & 0.123 & 0.182 & 0.209 & 0.288 & 0.316 \\ \text { Pacific Corp. } & 0.167 & 0.192 & 0.219 & 0.115 & 0.178 & 0.220 & 0.296 & 0.250 \\ \text { Pennsylvania P\&L } & \mathbf{0 . 2 3 9} & 0.143 & 0.156 & 0.175 & 0.172 & 0.165 & 0.286 & 0.292 \\ \text { Pinnacle West Capital } & 0.225 & 0.167 & 0.181 & 0.139 & 0.181 & 0.205 & 0.264 & 0.265 \\ \text { Potomac Electric Power } & 0.219 & 0.184 & 0.194 & 0.128 & 0.137 & 0.208 & 0.293 & 0.228 \\ \text { San Diego Gas \& Electric } & 0.152 & 0.147 & 0.160 & 0.149 & 0.198 & 0.201 & 0.329 & 0.303 \\ \text { Security Pacific } & 0.215 & 0.138 & 0.196 & 0.104 & 0.178 & 0.184 & 0.278 & 0.202 \\ \text { Union Electric } & 0.140 & 0.120 & 0.151 & 0.123 & 0.152 & 0.204 & 0.303 & 0.278 \\ \text { Washington Post } & 0.068 & 0.064 & 0.179 & 0.090 & 0.093 & 0.092 & 0.207 & 0.204\end{array}$


TABLE A-5

\section{Transition Matrix of Average Correlation Coefficients for Smaller Non-index Stocks by Calendar Years}

$\begin{array}{lllllllll}\text { Company } & 1980 & 1981 & 1982 & 1983 & 1984 & 1985 & 1986 & 1987 \\ & & & & & & & & \\ \text { Alco Standard } & 0.130 & 0.053 & 0.137 & 0.085 & 0.089 & 0.130 & 0.185 & 0.138 \\ \text { Ames Dept. Stores } & 0.136 & 0.162 & 0.165 & 0.124 & 0.107 & 0.110 & 0.133 & 0.128 \\ \text { Analog Devices } & 0.156 & 0.124 & 0.124 & 0.163 & 0.163 & 0.087 & 0.133 & 0.182 \\ \text { Arkla Inc. } & 0.179 & 0.093 & 0.155 & 0.099 & 0.072 & 0.022 & 0.094 & 0.175 \\ \text { Boston Edison } & 0.143 & 0.091 & 0.140 & 0.096 & 0.106 & 0.168 & 0.155 & 0.189 \\ \text { Central Illinois P.S. } & 0.169 & 0.130 & 0.125 & 0.113 & 0.115 & 0.134 & 0.188 & 0.210 \\ \text { Delmar P\&L } & 0.172 & 0.106 & 0.144 & 0.073 & 0.133 & 0.137 & 0.207 & 0.216 \\ \text { Harsco Corp. } & 0.116 & 0.083 & 0.144 & 0.075 & 0.097 & 0.090 & 0.117 & 0.143 \\ \text { Idaho Power } & 0.146 & 0.134 & 0.140 & 0.124 & 0.053 & 0.136 & 0.213 & 0.194 \\ \text { IPALCO Enterprises } & 0.174 & 0.125 & 0.160 & 0.114 & 0.123 & 0.188 & 0.211 & 0.270 \\ \text { Irving Bank } & 0.172 & 0.135 & 0.172 & 0.126 & 0.131 & 0.110 & 0.191 & 0.052 \\ \text { Kansas City P\&L } & 0.161 & 0.164 & 0.159 & 0.105 & 0.111 & 0.143 & 0.197 & 0.200 \\ \text { Kansas P\&L } & 0.179 & 0.129 & 0.161 & 0.109 & 0.108 & 0.159 & 0.185 & 0.183 \\ \text { Murphy Oil } & 0.165 & 0.107 & 0.166 & 0.122 & 0.088 & 0.053 & 0.092 & 0.148 \\ \text { Olin Corp. } & 0.154 & 0.126 & 0.194 & 0.129 & 0.140 & 0.087 & 0.203 & 0.206 \\ \text { Premier Industrial } & 0.092 & 0.114 & 0.108 & 0.072 & 0.108 & 0.153 & 0.129 & 0.138 \\ \text { Rochester Gas \& Elec. } & 0.108 & 0.105 & 0.095 & 0.096 & 0.131 & 0.151 & 0.176 & 0.158 \\ \text { Rorer Group } & 0.113 & 0.104 & 0.094 & 0.103 & 0.090 & 0.014 & 0.069 & 0.143 \\ \text { Staley Continental } & 0.182 & 0.100 & 0.118 & 0.111 & 0.090 & 0.116 & 0.107 & 0.188 \\ \text { Telex Corp. } & 0.147 & 0.159 & 0.153 & 0.090 & 0.178 & 0.099 & 0.150 & 0.110\end{array}$




\section{TABLE A-6}

\section{Average Correlation Coefficients for the MMI Stocks over High- and Low-Intensity Program Trading Days during 1987}

Company

American Express

American $T \& T^{b}$

Chevron

Coca-Cola

Dow Chemical

DuPont

Eastman Kodak

Exxon

General Electric

General Motors

IBM

International Paper

Johnson \& Johnson

Merck \& Co.

Minn. Mining \& Mfg.

Mobil

Philip Morris

Proctor \& Gamble

Sears

USX

Averages
High-Intensity Days ${ }^{\mathrm{a}}$

0.415

0.569

0.615

0.532

0.598

0.631

0.572

0.564

0.645

0.524

0.565

0.547

0.643

0.550

0.612

0.567

0.642

0.649

0.579

0.360
Low-Intensity Days

0.311

0.348

0.308

0.403

0.344

0.418

0.356

0.383

0.455

0.304

0.289

0.364

0.424

0.341

0.395

0.248

0.369

0.343

0.316

0.150
All Trading Days

0.345

0.406

0.404

0.439

0.420

0.484

0.411

0.443

0.513

0.376

0.383

0.418

0.495

0.398

0.459

0.355

0.443

0.433

0.402

0.194

a High-intensity days are defined as those trading days in which program trading volume in shares was equal to or greater than 4 percent of the total New York Stock Exchange volume in shares; all other days are defined as low-intensity days.

b AT\&T, which resulted from a court-ordered breakup of the Bell System, received about 23 percent of the former company's assets. Therefore, post-divestiture data after 1983 are not comparable to the predivestiture data. 


\section{TABLE A-7}

\section{Average Correlation Coefficients for the Largest Non-MMI Stocks in the S\&P 500 Index over High- and Low-Intensity Program Trading Days during 1987}

Company

High-Intensity Days*

Low-Intensity Days

0.400

0.295

0.292

0.300

0.126

0.399

0.316

0.411

0.303

0.324

0.323

0.366

0.364

0.370

0.361

0.329

0.279

0.118

0.363

0.406

0.322

Averages

0.481
All Trading Days

0.440

0.369

0.353

0.364

0.173

0.443

0.372

0.456

0.349

0.367

0.356

0.410

0.420

0.394

0.394

0.380

0.241

0.134

0.422

0.448

0.364

* High-intensity days are defined as those trading days in which program trading volume in shares was days are defined as low-intensity days. 


\section{TABLE A-8}

\section{Average Correlation Coefficients for Smaller Index Stocks in the S\&P 500 Index over High- and Low-Intensity Program Trading Days during 1987}

Ahmanson, H.F.

0.333

Amax Inc.

0.251

Armstrong World Indus.

0.236

Bethlehem Steel

0.146

Black \& Decker

0.297

Brown-Forman Distillers

0.309

Coastal Corp.

0.316

Combustion Engineering

0.235

Consolidated Freightways

0.212

Data General

0.154

E.G. \& G

0.289

Firestone Tire \& Rubber

0.297

Great Northern Nekoosa

0.349

Great Western Financial

0.372

0.328

INTERCO, Inc.

0.158

Louisiana Land \& Expl.

Owens-Corning-Fiberglas

Polaroid

0.272

0.413

0.331

Williams Cos.

0.200

Averages

0.275
0.231

0.082

0.202

0.129

0.181

0.181

0.201

0.222

0.229

0.190

0.238

0.241

0.248

0.231

0.186

0.193

0.257

0.174

0.147

0.092

0.193
0.256

0.116

0.225

0.137

0.219

0.220

0.241

0.227

0.232

0.173

0.253

0.256

0.281

0.274

0.230

0.204

0.271

0.244

0.190

0.124

0.219

* High-intensity days are defined as those trading days in which program trading volume in shares was equal to or greater than 4 percent of the total New York Stock Exchange volume in shares; all other days are defined as low-intensity days. 


\section{TABLE A-9}

\section{Average Correlation Coefficients for the Largest Non-index Stocks over High- and Low-Intensity Program Trading Days during 1987}

Company

\author{
High-Intensity Days*
}

Affiliated Publications

Allegheny Power System

0.176

0.399

Ashland Oil

Carolina P\&L

0.264

0.389

Centel Corp.

0.244

0.244

0.211

0.354

0.220

0.345

0.315

0.312

0.361

0.296

0.207

0.094

0.424

0.303

0.291

0.340

Pennsylvania P\&L
Low-Intensity Days

All Trading Days
0.162

0.319

0.170

0.112

0.300

0.199

0.201

0.128

0.257

0.272

0.221

0.244

0.309

0.218

0.293

0.290

0.265

0.280

0.173

0.269

0.163

0.234
0.331

0.144

0.316

0.215

0.218

0.149

0.280

0.265

0.255

0.266

0.316

0.250

0.292

0.265

0.228

0.303

0.202

0.278

0.204
0.247

Averages

0.289

* High-intensity days are defined as those trading days in which program trading volume in shares was equal to or greater than 4 percent of the total New York Stock Exchange volume in shares; all other days are defined as low-intensity days. 


\section{TABLE A-10}

\section{Average Correlation Coefficients for Smaller Non-index Stocks over High- and Low-Intensity Program Trading Days during 1987}

Company

Alco Standard

Ames Dept. Stores

Analog Devices

Arkla Inc.

Boston Edison

Central Illinois P.S.

Delmar P\&L

Harsco Corp.

Idaho Power

IPALCO Enterprises

Irving Bank

Kansas City P\&L

Kansas P\&L.

Murphy Oil

Olin Corp.

Premier Industrial

Rochester Gas \& Electric

Rorer Group

Staley Continental

Telex Corp.

Averages
High-Intensity Days *

0.019

0.145

0.123

0.199

0.141

0.228

0.169

0.168

0.155

0.217

0.198

0.201

0.125

0.236

0.113

0.095

0.081

0.170

0.178

0.007

0.148
Low-Intensity Days

All Trading Days

0.158

0.121

0.194

0.169

0.201

0.203

0.235

0.139

0.202

0.280

0.036

0.209

0.205

0.120

0.223

0.151

0.182

0.135

0.196

0.175

0.177
0.138

0.128

0.182

0.175

0.189

0.210

0.216

0.143

0.194

0.270

0.052

0.200

0.183

0.148

0.206

0.138

0.158

0.143

0.188

0.110

0.169

* High-intensity days are defined as those trading days in which program trading volume in shares was equal to or greater than 4 percent of the total New York Stock Exchange volume in shares; all other days are defined as low-intensity days. 


\section{REFERENCES}

Bierman, H. 1988. "Defining and Evaluating Portfolio Insurance Strategies." Financial Analysts Journal 44 (May/June): 84-87.

Blume, M. 1975. "Betas and Their Regression Tendencies." Journal of Finance 30 (June): $785-96$.

Box, G.E.P. 1949. "A General Distribution Theory for a Class of Likelihood Criteria." Biometrika 36: 317-46.

Cho, D. C. and W.M. Taylor. 1987. "The Seasonal Stability of the Factor Structure of Stock Returns." Joumal of Finance 42 (December): 1195-1211.

Cornell, B. 1985. "Taxes and the Pricing of Stock Index Futures: Empirical Results." Journal of Futures Markets 5 (Spring): 89-101.

Cornell, B. and K.R. French. 1983. "The Pricing of Stock Index Futures." Jourmal of Futures Markets 3 (Winter): 1-14.

Dattatreya, R. and M.A. Zurack. 1985. “Asset Allocation Using Futures Contracts.” Goldman, Sachs \& Co. Research Report (February).

Edwards, F.R. 1988. "Does Futures Trading Increase Stock Market Volatility?" Financial Analysts Journal 44 (January/February): 63-69.

Elton, E.J. and M.J. Gruber. 1973. "Estimating the Dependence Structure of Share Prices." Journal of Finance 28 (December): 1203-32.

Elton, E.J., M. J. Gruber, and M. W. Padberg. 1976. "Simple Criteria for Optimal Portfolio Selection." Journal of Finance 31 (December): 1341-57.

Elton, E.J., M. J. Gruber, and T. J. Urich. 1978. “Are Betas Best?” Journal of Finance 33 (December): 1375-84.

Farrell, J.L. 1974. "Analyzing Covariation of Returns to Determine Homogeneous Stock Groupings." Journal of Business 47 (April): 186-207. 
Figlewski, S. 1984a. "Hedging Performance and Basis Risk and Stock Index Futures." Journal of Finance 39 (July): 657-69.

- 1984b. "Explaining the Early Discounts on Stock Index Futures: The Case for Disequilibrium.” Financial Analysts Joumal 40 (July/August): 43-47.

— 1985. "Hedging with Stock Index Futures: Theory and Application in a New Market." Journal of Futures Markets 5 (Summer): 183-99.

Figlewski, S. and S.J. Kon. 1982. "Portfolio Management with Stock Index Futures." Financial Analysts Journal 38 (January/February): 52-60.

Finnerty, J.E. and H.Y. Park. 1987. "Stock Index Futures: Does the Tail Wag the Dog?” Financial Analysts Journal 43 (March/April): 57-61.

Fong, G. 1980. "An Asset Allocation Framework." Journal of Pontfolio Management 6 (Winter): 58-66.

Fouse, W.L. 1987. "The Evolution of Asset Allocation Theory and Practice." In Asset Allocation for Institutional Portfolios. Charlottesville, Va: Association for Investment Management and Research.

Gordon, J.D., E.J. Moriarty, and P.A. Tosini. 1987. "Stock Index Futures: Does the Dog Wag the Tail?" Financial Analysts Journal 43 (November/December): 72-73.

Gould, F. J. 1988. "Stock Index Futures: The Arbitrage Cycle and Portfolio Insurance.” Financial Analysts Journal 44 (January/February): 48-62.

Graham, D. and R. Jennings. 1987. "Systematic Risk, Dividend Yield and the Hedging Performance of Stock Index Futures.” Joumal of Futures Markets 7 (Spring): 1-13.

Grant, D. 1982. "How to Optimize with Stock Index Futures." Journal of Portfolio Management 8 (Spring): 32-36.

Grossman, S.J. 1988a. "Program Trading and Market Volatility: A Report on Interday Relationships." Financial Analysts Journal 44 (July-August): 18-28.

— 1988b. "Program Trading and Stock and Futures Price Volatility." Journal of Futures Markets 8 (August): 413-19. 
Harris, L. 1989. "The October 1987 S\&P 500Stock-Futures Basis." Journal of Finance 44 (March): 77-99.

Hill, J.M. and F.J. Jones. 1988. "Equity Trading, Program Trading, Portfolio Insurance, Computer Trading and All That." Financial Analysts Joumal 43 (July/ August): 29-38.

Junkus, J. and C. Lee. 1984. "Use of Three Stock Index Futures in Hedging Decisions." Journal of Futures Markets 4 (Spring): 34-40.

Kawaller, I.G., P.D. Koch, and T.W. Koch. 1987. "The Temporal Price Relationship between S\&P 500 Futures and the S\&P 500 Index." Jourmal of Finance 42 (December): $1309-30$.

Klemkosky, R.C. and J.D. Martin. 1975. "The Adjustment of Beta Forecasts." Journal of Finance 30 (September): 1123-28.

Kling, A. 1987. "How the Stock Market Can Learn to Live with Index Futures and Options." Financial Analysts Journal 43 (September/October): 33-39.

MacKinlay, AC. and K Ramaswamy. 1988. "Index-Futures Arbitrage and the Behavior of Stock Index Futures." Review of Financial Studies 1 (Summer): 137-58.

Martin, J.D. and A.J. Senchack, Jr. 1989. "Program Trading and Systematic Stock Price Behavior." Financial Analysts Journal 45 (May/June): 61-67.

Modest, D. and M. Sundaresan. 1983. "The Relationship Between Spot and Futures Prices and Stock Index Futures Markets: Some Preliminary Evidence." Journal of Futures Markets 3 (Summer): 15-41.

Modest, D.M. 1984. "On The Pricing of Stock Index Futures." Journal of Pontfolio Management 10 (Spring): 51-57.

Morrison, D. 1976. Multivariate Statistical Analysis. New York: McGraw-Hill.

Nordhauser, F. 1984. "Using Stock Index Futures to Reduce Market Risk." Journal of Portfolio Management 10 (Spring): 56-62. 
Roll, R 1988. “The International Crash of October 1987." Financial Analysts Joumal 44 (September/October): 19-35.

Rubinstein, M. 1988. "Portfolio Insurance and the Market Crash." Financial Analysts Journal 44 (January/February): 38-47.

— 1989. “Market Basket Alternatives.” Financial Analysts Journal 45 (September/October): 20-29.

Sorenson, E.H. and T. Burke. 1986. "Portfolio Returns from Active Industry Group Rotation." Financial Analysts Journal 42 (September/October): 43-50.

Stoll, H. 1988. "Portfolio Trading." Journal of Ponffolio Management 14 (Summer): 20-24.

Stoll, H.R. and R.E. Whaley. 1987. "Program Trading and Expiration-Day Effects." Financial Analysts Journal 43 (March/April): 16-28.

. 1990. "Program Trading and Individual Stoc
the Triple Witching Brew." Journal of Business 63: S165-92.

Tosini, P.A. 1982. "Potential Hedging Use of a Futures Contract Based on a Composite Stock Index.” Joumal of Futures Markets 2 (Spring): 83-102.

— . 1988. "Stock Index Futures and Stock Market Activity in October 1987." Financial Analysts Journal 44 (January/February): 22-37.

Treynor, J.L. 1988. "Portfolio Insurance and Market Volatility." Financial Analysts Journal 44 (November/December): 71-73.

Vasicek, OA 1973. "A Note on Using Cross-Sectional Information in Bayesian Estimation of Security Betas." Journal of Finance 28 (December): 1233-39.

Weiner, N.S. 1981. "The Hedging Rationale for a Stock Index Futures Contract." Journal of Futures Markets 1 (Spring): 59-76.

Weiss, G. 1989. “Seeing Double in Program Trading." Business Week (November 20): 31-32. 